\title{
Feasibility of Rainwater Harvesting and Consumption in a Middle Eastern Semiarid Urban Area
}

\author{
Ehsan Ranaee ${ }^{1,2, *(\mathbb{C},}$, Ali Akbar Abbasi ${ }^{1}$, Javad Tabatabaee Yazdi ${ }^{1}$ and Maryam Ziyaee ${ }^{3}$ \\ 1 Agriculture and Natural Resources Research Center of Khorasan Province (KANRRC), \\ Mashhad 1696700, Iran; ak_abbasi@yahoo.com (A.A.A.); tabatabaee_j@yahoo.com (J.T.Y.) \\ 2 Dipartimento di Energia, Politecnico di Milano, via Lambruschini 4, 20156 Milano, Italy \\ 3 Dipartimento di Architettura e Studi Urbani, Politecnico di Milano, via Bonardi 3, 20133 Milano, Italy; \\ maryam.ziyaee@polimi.it \\ * Correspondence: ehsan.ranaee@polimi.it; Tel.: +39-02-2399-8431
}

Citation: Ranaee, E.; Abbasi, A.A.; Tabatabaee Yazdi, J.; Ziyaee, M. Feasibility of Rainwater Harvesting and Consumption in a Middle Eastern Semiarid Urban Area. Water 2021, 13, 2130. https://doi.org/ $10.3390 /$ w13152130

Academic Editor: Pedro MartínezSantos

Received: 30 June 2021

Accepted: 26 July 2021

Published: 2 August 2021

Publisher's Note: MDPI stays neutral with regard to jurisdictional claims in published maps and institutional affiliations.

Copyright: (c) 2021 by the authors. Licensee MDPI, Basel, Switzerland. This article is an open access article distributed under the terms and conditions of the Creative Commons Attribution (CC BY) license (https:/ / creativecommons.org/licenses/by/ $4.0 /)$.

\begin{abstract}
Recent developments of Middle Eastern metropolitans, and the related soaring trend of population increase, is contemporary with the impacts of climate changes. This applies extra pressures to the centralized large-scale water treatment and distribution systems. Rainwater harvesting (RWH) for domestic urban activities can be a sustainable option of adapting with the rising demand of soft water in such an arid/semiarid area. A pilot system of rainwater draining and storage was constructed for alleviating parts of soft water scarcity in Mashhad, the second most populous city of Iran. Measurements were collected for two years at the drainage basin outlet and inside of a storage tank, which has been equipped for water harvesting purposes. We performed some preliminary stochastic analysis and evaluated probabilistic properties of the collected dataset, aiming to explain them with respect to the physical characteristics of the RWH system. Data clustering analysis confirmed that the quality of the water may change during rainwater draining and storage in the RWH tank. Particularly, sodium content of the sampled water in the drainage catchment illustrated higher variations, compared with the ones evaluated for the stored water in the reservoir tank. This can confirm that the quality of the stored water in the RWH reservoir is more stable than that obtained for each separate rainfall-runoff event. We assessed the potential of the harvested water in different consumption contexts, in light of some national and international water quality (physicochemical, biological, and toxic pollutants) guidelines. We relied on water quality indices (WQI) to interpret multiparametric properties of the collected rainwater from urban surfaces; consequently, the quality of the harvested water was categorized with moderate to almost good attributes. This makes it well suited for irrigation uses, which can play a relevant role against water shortages in the analyzed semiarid urban region. Otherwise, infiltration and treatments need to be performed if using harvested water for drinking consumptions (of human or livestock), some of which may be costly for local owners/uses. We provide some suggestions for improving efficiency of the system and enhancing the quality of the harvesting water.
\end{abstract}

Keywords: urban rainwater harvesting; sustainable water supply; semiarid region; climate coefficient; water quality index; data-driven analysis

\section{Introduction}

Recently, the COVID-19 pandemic has reinforced the awareness that underestimating risks of global and natural hazards can lead to unrecoverable negative effects on the Earth ecosystem and society [1]. The risk of a water crisis is a serious element of global concern [2]. It is estimated that over half of the global population will suffer water scarcity by the next two decades [3]. This situation is even more challenging in developing countries of arid/semiarid regions, where climate change can form zones of various climates with high frequency of droughts and precipitation [4]. Population growth, urbanization, and industri- 
alization can manifold pressure of water shortage in such semiarid area. A comprehensive management policy is then needed to address such issues ([5] and references therein).

The Iranian society is dealing with water shortage issues that are inherent to semiarid regions. An incomplete design and implementation of effective strategies for water resources management has led to an acute water crisis. Overexploitation has plagued the area in recent decades due to the increasing needs related to water demands. Dealing with water scarcity is even more challenging in the presence of (i) climate changes and/or (ii) population dynamics and conflicts as a consequence of socio-economic transformations, including migration from rural to urbanized areas [6].

The region is facing depletion and deterioration of some important aquifer systems. Cities and rural regions are suffering from seasonal soft water scarcity as well as stormwater events [7]. The available per capita freshwater in Iran has been reduced by almost one quarter in recent decades (e.g., with a decrease from $2000 \mathrm{~m}^{3}$ in the year 2000 to $1560 \mathrm{~m}^{3}$ in 2017). These issues indicate that the Country is already subject to a rather alarming water stress [8].

A driving force-pressure-state-impact-response-outlook analysis has been recently performed [9] to evaluate general conditions of water resources in Iran. The study concluded that water resources management is a challenging issue for the country due to (i) uneven distribution of population and economic activities, (ii) inadequate monitoring of water pollution sources, (iii) incomplete cooperation among relevant governmental and nongovernmental organizations, and (iv) inadequate guidelines and standards. The authors also showed that the main pressure on water resources of Iran is in the agriculture sector. Besides, socio-economic development of the urban and industrial areas, as triggered by governmental policies from mid-20th century [8], has led to increasing migrations to the largest cities.

In such circumstances, present work is set to analyze the feasibility of performing rainwater harvesting (RWH) as an alternative to answer some parts of water supply in Iran. RWH systems are designed to collect runoff from urban/rural land surfaces, rooftops, steep slopes, and road surfaces during yielding rain periods, and store it in tanks, storage reservoirs, sand dams, check dams, or underground dams for future uses [10]. Some resent studies evaluated RWH as one of the most promising technologies to cope with water scarcity and pollution in urban area [5,11]. A typical RWH system includes three essential elements: (i) catchment area, (ii) storage devices, and (iii) conveyance system [12]. Impermeable urban surfaces (e.g., building roofs, parking, streets, pavements, and sidewalks) in cities can offer valuable opportunities of catchment area for RWH.

The efficiency of a RWH project, in a primary stage, is in direct relation with the probability of the occurence (and intensity) of rainfall events [13]. In addition, local circumstances of a RWH project, including (i) consumption purpose of the harvesting water, (ii) construction technical concerns, (iii) economic budget, and (iv) socio-political conditions, should be taken into consideration [14]. Campisano, et al. [15] analyzed some technical and social aspects of RWH and argued that technology selection of RWH is mainly influenced by economic constraints and local regulations. A review on available technologies associated with RWH projects in least developed countries is offered in [16]. These authors analyzed key characteristics of RWH techniques and suggested a decision-making framework for the quantification of requirements and benefits related to diverse RWH technologies to meet case-specific domestic and/or agricultural water demands. They then estimated that construction of a large RWH system (with a capacity larger than $500 \mathrm{~m}^{3}$ ) requires high economic investments, which can be comparable to those needed for a large-scale water storage reservoir. Costs and benefits of rainwater harvesting systems and their comparison against those associated with a large-scale central water supply system of a town are analyzed in [17]. The authors relied on the assessment of energy intensity (i.e., unit of energy per unit of water) to decide about economic feasibility and optimization of a RWH project. The authors inferred that rainwater demand, building type, RWH system 
design, and town water energy intensity are the main elements influencing economic and environmental performance of a RWH project.

While the establishment of a local RWH system was shown to be associated with a low cost and ease of technological installation [18], overcoming challenges associated with seasonality of rainwater availability would require the construction of large reservoirs, which is, in turn, associated with considerable financial investments. Additionally, storing water for a long time is prone to negative effects associated with the deterioration of quality. Economic benefits stemming from installing RWH systems are analyzed in [19] considering increasing demands of soft water in major cities of Bangladesh. The authors reported that some urban communities are not confident enough about the adoption of RWH systems due to risks associated with (i) potential water savings and (ii) payback period on initial investments. The study suggests that the efficiency of rainwater harvesting systems may change due to the temporal variability of rainfall and the size of the installed RWH tanks. Otherwise, due to quality concern and lack/cost of treatment facility, the authors suggest to avoid designing RWH systems for human drinking purposes in Bangladesh. Elements associated with government rebates for the installation of rainwater tanks in Sydney are analyzed in [20]. The authors suggest that increasing collecting surfaces (e.g., rooftops, steep slopes, and road surfaces) is more efficient for maximizing rainwater harvesting and savings than increasing the capacity of the existing storage tanks.

Small-scale RWH systems are sustainable approaches to answer a quota of soft water supply for domestic activities [21]. Irrigation of rainfed crops through RWH for domestic gardening and agriculture is a viable option to increase productivity and crop yields [22]. From a private household perspective, an investment in a small-scale RWH system will be convincing only if the returning time is less than a few years [23]. Bouma et al. [24] assessed agricultural returns to investments in small-scale RWH projects and confirmed that pay-back time would be reasonably convincing. They also accounted for variability in the quality of the rainy season for a period of 10 years. The authors suggested that RWH can increase domestic agricultural productions by roughly $78 \%$ (on average) across Asian and African territories.

An entry point for designing a domestic RWH system is decision-making regarding the target supply/consumption purpose (e.g., drinking, agricultural, or industrial) of harvesting water [25], and water quality plays an essential role in such decision-making [26]. Naus et al. [18] analyzed the potential of some alternative options (including RWH) to replace unsafe drinking water options in Bangladesh and argued that global acceptance of safe drinking water options varies among user communities and is not necessarily guaranteed. Likely pollution of harvesting rainwater with physicochemical/microbiological contaminants during drainage and/or storage stages of RWH is a serious concern that may threaten the success of a RWH project in urban area. Accordingly, the quality of the harvesting rainwater should be adequately evaluated. Sheikh [5] recently assessed public perception and attitudes towards RWH by Iranian citizens of various socio-geographic characteristics. He reported rainwater quality and financial cost as main concerns of both public and experts for RWH projects. The author suggested the necessity of increasing public awareness, involvement, and support to prevent threats of consuming harvested rainwater.

In this framework, we designed and installed a pilot RWH project in the city of Mashhad (Iran), with the overall aim of assessing the potential of the collected water to serve across a variety of (sometimes competitive) uses. Specifically, our study is keyed to the analysis of aspects related to the quality of the water associated with the RWH system in light of national/international water quality standards.

Some studies have reported public health risk of using rainwater while it may carry hazardous chemicals, bacteria, and microbial pathogens ([27] and references therein); accordingly, collected rainwater may require some necessary treatments before usage. Rainwater far from urban and industrial area generally has acceptable quality (except for some dissolved gases). Instead, rainwater in urban area may be contaminated by heavy metals, particles, and organic compounds that are washed out from the atmosphere 
and/or catchment basin during rainfall events [28]. Rainwater may also react (physicochemically) with the materials of urban surfaces, which influences quality of the water over collecting/storage times. Lee et al. [28] assessed the quality of harvested rainwater for domestic uses, on the basis of utilizing some different roofing materials for RWH catchment. Their analysis showed that the type of roofing material used has some influence on the quality of the harvested rainwater. Ahmed et al. [29] conducted a literature review and argued that microbial quality of harvested rainwater may follow more highly oscillating trends than may commonly be perceived. The authors noticed that the quality of collected water in a RWH system can be strongly affected by seasonal number of dry days, geographical location, land uses, and activities.

Water quality should satisfy a set of standards, which may differ for human drink, livestock consumptions, irrigation uses, and environmental concerns [30]. For agricultural uses, rainwater may be collected from a drainage basin and stored underground in natural systems protecting it from evaporation. Sazakli et al. [31] investigated a RWH project in Kefalonia Island, in Greece, and argued that the chemical quality of the harvested rainwater is satisfying for domestic agricultural water supply purposes. Helmreich and Horn [32] suggested to perform slow sand filtration and solar technology to reduce pollution of the collected rainwater for agricultural consumptions. Indeed, further treatments are recommended for drinking water supply [29,33]. Rainwater collected (typically from rooftops or courtyards) for human consumptions needs to be stored in underground or surface tanks and disinfected [32]. Helmreich and Horn [32] suggested that performing membrane disinfection can reasonably enhance harvested water quality for drinking supply.

Following the 2030 vision of the World Health Organization, WHO, Howard and Bartram [34] for the resilience of water supply and sanitation, the Agriculture and Natural Resources Research Center of Khorasan province (KANRRC) of Iran has equipped a couple of RWH pilots to assess the feasibility of performing rainwater harvesting, as a supplementary resource of answering parts of soft water demand in Mashhad city. In this framework, a system of rainwater draining and storage was constructed and equipped in two hectares urban area inside KANRRC. Measurements related to the rainfall-runoff quantity and stored water quality have been collected for two years at the catchment outlet, as well as inside a storage tank that has been established in the urban area for water harvesting purposes. We evaluate the quality of the collected rainwater on the basis of some physicochemical and microbiological parameters; and suggest some potential opportunities of the consuming harvesting water, in light of available national and international water quality regulations.

We also include a stochastic analysis of the available observations associated with the quantities/parameters selected to characterize the quality of the harvested water. The stochastic analysis is structured across three steps: (i) quantification of the degree of possible correlations between parameters representing chemical properties of the harvested water; (ii) reduction of the dimensionality of the space identified by these parameters through principal components analysis (PCA); (iii) clustering of data. With reference to the latter point, we recall that clustering technique can assist delineating key system features [35]. Such an analysis can enable one to explore intrinsic relationships between locations (i) in space (i.e., inside drainage basin or storage tank) and (ii) in time (i.e., rainfall events or storage time) where one can plan efficient sampling of water quality data. To this end, relying on a PCA approach is appealing because it yields a straightforward (a) identification of the main features for classification [36] and (b) reduction of the system dimensionality to enable us to clearly assess interdependences of the analyzed water quality parameters. Clustering is performed upon projecting the available data onto a set of linear principal components (PCs).

The manuscript is organized as follows. Section 2 provides key theoretical elements underpinning the study. Implementation of the analysis workflow and the ensuing results are discussed in Section 3. Key outcomes of the study and concluding remarks are presented in Section 4, some recommendations being then provided in Section 5. Details about the 
evaluation of climate and hydrologic conditions of the region under study are included in Appendices A and B, respectively.

\section{Materials and Methods}

This section provides theoretical aspects of our analysis workflow. We briefly describe in Section 2.1 a synthesis of the key theoretical elements of the data-driven stochastic analysis and PCA-based data clustering technique. Water quality indices (WQI) of interpreting quality of underground/surface water resources are presented in Section 2.2.

\subsection{PCA-Based Data Clustering}

As a preliminary analysis, we perform data-driven clustering analysis to the values of sampled water from the RWH system and try to link stochastic behavior of the collected dataset to some physical characteristics of the established RWH system. In this framework, we first transform sampling values of the water quality parameters to the space of principal components (PCs) and then perform k-means clustering [35] to the transformed dataset.

Measurements of a real-world phenomenon, in most cases, are obtained in a multidimensional space. An illustration of a cloud of sampling observations locates data in a multidimensional space, whose coordinate axes are placed on measurement variables. An alternative approach to represent the cloud of measurements is to transfer the coordinate axes from measurement variables to the center (i.e., mean) of samples and rotate the axes to the directions where data have the largest projection (i.e., variance). One can take the first axis to the direction where sampled measurements have the largest variance, as the first PC. The next axis aligns to the direction where data points show the second largest projected variance. For simplicity and applicability purposes, we can set this principal coordinate system to be orthogonal [36]. This data-dependent coordinate system (principal coordinate) can be adapted for stochastic analysis and data classification. The original (measurement based) coordinate system can be related to the principal coordinate system by implementing a translation and rotation in a PCA framework [37]. By evaluating parameters of such transformation analysis, we can obtain valuable information about structure of the collected dataset and characteristics of the analyzing system. This information can be used for further decision-making about priority and/or classification of the collecting measurements needed for characterization of the phenomena being studied.

Assume a set of measurement samples are gathered in a data matrix $X^{*} \in \mathbb{R}^{N \times M}$, formed by $N$ rows that comprise experimental sampling data of the $M$ variables (i.e., water quality parameters for the present work). Principal components can be computed as the right eigenvectors of the following covariance matrix:

$$
\boldsymbol{C}_{x}=\frac{1}{N} \boldsymbol{X}^{* T} \boldsymbol{X}^{*}
$$

which satisfy

$$
\lambda_{i} v_{i}=C_{x} v_{i} \text { with } i=1, \ldots, M
$$

The superscript * identifies experimental observations, and $T$ denotes transpose. Then $M$ principal components of the analyzing system correspond to the eigenvectors $v_{i}$ of the Equation (2) and are ranked according to the values of the related eigenvalues, $\lambda_{i}$. The overall variability of $X^{*}$ will be equal to the summation over the full set of $\lambda_{i}$. PCs can then be ranked according to their capabilities to project variance of the dataset $\boldsymbol{X}^{*}$. The quota of the variance explained by $i$-th PC is defined as the ratio of the eigenvalue, $\lambda_{i}$, to the overall variability of $\boldsymbol{X}^{*}$.

We performed $k$-means clustering to iteratively partition the data points that are projected into the principal coordinate system. To increase reliability of clustering, we considered as many PCs as covering a reasonable percentage of variance content of the complete dataset. Data points classified in a cluster should be as close to each other as possible, and as far from data points in other clusters as possible [35]. Each cluster is characterized 
by its members, $x_{j}$, and the corresponding centroid, $\bar{x}_{k}$. In this way, Euclidean, $E_{k}$, index is a measure of distances between the points and the centroid of each chosen cluster.

$$
E_{k}=\sqrt{\left(\sum_{j=1}^{N}\left(x_{j}-\bar{x}_{k}\right)^{2}\right)} \text { with } \bar{x}_{k}=\frac{x_{j}}{n_{k}}
$$

where $N$ is the total number of data points, and $n_{k}$ indicates the number of objectives assigned to the $k$-th cluster.

Calculations run over all $k$ clusters and $k$-means clustering technique try to iteratively choose $\bar{x}_{k}$ in the case that the summation of the distances from (3) are minimized. The result is a set of clusters that are as compact and well separated as possible [35].

To quantify goodness of the clustering, we can calculate Silhouette [38] indices, $I_{S_{j}}$, as follow:

$$
I_{S_{j}}=\frac{b_{j}-a_{j}}{\max \left\{b_{j}, a_{j}\right\}} \text { with } \bar{x}_{k}=\left\{\begin{array}{c}
1-\frac{a_{j}}{b_{j}}, \text { if } a_{j}<b_{j} \\
0, \text { if } a_{j}=b_{j} \\
a_{j}-1, \text { if } a_{j}<b_{j}
\end{array}\right.
$$

where $a_{j}$ is average distance of the $j$-th data point in each cluster within the other data in the same cluster, and $b_{j}$ is the minimum average distance from $j$-th data point to the ones in a neighboring cluster, minimized over cluster.

The silhouette displays a measure of how far each point in one cluster is to the points in the neighboring clusters. This measure ranges from +1 , indicating points that are very distant from neighboring clusters, through zero, indicating points that are not distinctly in one cluster or another, to -1 , indicating points that are probably assigned to the wrong cluster.

\subsection{Water Quality Assessment}

Quality of a water resource reflects combination effects of the climatical, hydrologic, geological, and environmental situations of the region, as well as demographic and social behavior of the residents. Monitoring and assessment of the water resources quality can serve us valuable information on interactions of such characteristic elements and help with decision-making about the suitability of water resources for different applications [39].

Water quality assessment of the public distribution networks typically monitors for different chemical elements and biological contaminants to ensure compliance with available standards [40]. However, standards for domestic water suppliers are not well regulated. WHO has suggested some guidelines for the assessment of water quality [33,41]. Such guidelines do not intend to serve as water quality standards; instead, individual countries can benefit from them as a basis to develop appropriate water quality standards and regulations in the context of environmental, social, economic, and cultural conditions of their territories. Then, it is obvious that national water quality standards may differ from one country to another one. Regulations may also vary depending on target consumption of the supplying water. We collected here some national [42] and international [33,43,44] water quality regulations and standards as reported in Table 1.

In 2013, the Iranian Department of Environmental Protection (IDEP) adapted the national regulations for surface water quality [42]. The suggested limitations of those regulations vary depending on target uses of the surface water for (i) drinking consumptions, (ii) agricultural uses, and (iii) environmental sustainability needs. These standards also differ accounting for the level of water purification (filtration and/or refinements) that is needed before using. In Table 1 we provide minimum requirements of the surface water quality that can be used (after filtration and simple disinfection). In Section 3, we will refer to the guidelines of Table 1 , analyze the quality of the harvesting water, and suggest some target consumptions of the harvested rainwater in Mashhad urban area. 
Table 1. The utilized national and international water quality standards. Standards refer to (i) $\mathrm{S}_{1}$ : WHO [33] guidelines for drinking water quality, (ii) $\mathrm{S}_{2}$ : FAO guidelines [43] for agricultural water quality, and national standards [42] of (iii) $\mathrm{S}_{3}$ : drinking water quality, (iv) $\mathrm{S}_{4}$ : agricultural water quality, and (v) $\mathrm{S}_{5}$ : environment concerns of wastewater sewage.

\begin{tabular}{|c|c|c|c|c|c|c|}
\hline \multirow{3}{*}{\multicolumn{2}{|c|}{$\begin{array}{c}\text { Water Quality } \\
\text { Parameters }\end{array}$}} & \multicolumn{2}{|c|}{ International Guidelines } & \multicolumn{3}{|c|}{ National Standards of Surface Water } \\
\hline & & $\mathrm{S}_{1}$ & $\mathrm{~S}_{2}$ & $\mathrm{~S}_{3}$ & $\mathrm{~S}_{4}$ & $\mathrm{~S}_{5}$ \\
\hline & & Drinking Water & Irrigation Water & Drinking Uses $^{1}$ & Irrigation Uses & $\begin{array}{c}\text { Environmental } \\
\text { Concerns }\end{array}$ \\
\hline \multicolumn{2}{|c|}{$\mathrm{PH}$} & $6.5-8.5$ & $6.5-8.5$ & $6.5-8.5$ & $6-8.5$ & $6-9$ \\
\hline \multicolumn{2}{|c|}{$\mathrm{TH}(\mathrm{mg} / \mathrm{L})$} & $<500$ & $<2000$ & $<500$ & - & - \\
\hline \multicolumn{2}{|c|}{ TDS (mg/L) } & $<500$ & $<2000$ & $<500$ & $<1500$ & - \\
\hline \multicolumn{2}{|c|}{$\mathrm{EC}(\mu \mathrm{S} / \mathrm{cm})$} & $<300$ & $<3000$ & $<1000$ & $<3000$ & - \\
\hline \multicolumn{2}{|c|}{ Total Coliforms (\#/100 mL) } & 0 & $<100$ & $<50$ & $<1000$ & $<1000$ \\
\hline \multicolumn{2}{|c|}{ Fecal Coliforms (\#/100 mL) } & 0 & - & $<20$ & $<400$ & $<400$ \\
\hline \multicolumn{2}{|c|}{$\mathrm{BOD}_{5}(\mathrm{mg} / \mathrm{L})$} & $<5$ & $<30$ & $<3$ & $<100$ & $<30$ \\
\hline \multicolumn{2}{|c|}{$\mathrm{COD}(\mathrm{mg} / \mathrm{L})$} & $<15$ & $<50$ & & $<200$ & $<60$ \\
\hline \multicolumn{2}{|c|}{ Color (CU) } & $<15$ & - & $<20$ & - & $<75$ \\
\hline \multicolumn{2}{|c|}{ Turbidity (NTU) } & $<5$ & - & $<25$ & $<50$ & $<50$ \\
\hline \multicolumn{2}{|c|}{$\mathrm{DO}(\mathrm{mg} / \mathrm{L})$} & $>5$ & - & $>7$ & $>2$ & $>2$ \\
\hline \multicolumn{2}{|c|}{$\mathrm{Na}(\mathrm{mg} / \mathrm{L})$} & $<200$ & $<200$ & $<200$ & - & - \\
\hline \multirow{4}{*}{$\begin{array}{l}\text { Heavy Metals } \\
\text { (ppb) }\end{array}$} & $\mathrm{Pb}$ & $<10$ & $<5000$ & $<10$ & $<500$ & $<1000$ \\
\hline & $\mathrm{Cd}$ & $<3$ & $<10$ & $<3$ & $<10$ & $<100$ \\
\hline & $\mathrm{Ni}$ & $<20$ & $<200$ & - & $<20$ & $<2000$ \\
\hline & $\mathrm{Cr}$ & $<50$ & $<100$ & $<50$ & $<100$ & $<2000$ \\
\hline
\end{tabular}

${ }^{1}$ Reported values refer to standards of the surface water quality to be used for drinking purposes, after performing filtration and simple disinfections.

Water quality indices (WQI) are simple and efficient tools of interpreting and summarizing multidimensional pollution conditions of the surface or underground water resources being studied. WQI indices are typically empirical formulations that weight values of some water quality elements (based on their importance) and integrate them to come up with a classification indicator of safety (varying in a range of unfit to excellent) of the analyzed aqueous natural resource for our target (e.g., drinking, agricultural, or industrial) consumption.

Different WQIs are developed by national and international agencies of water pollution control [45]. Iranian Water Resources Management [42] developed an index for the assessment of the quality (including conventional and toxic parameters) of surface and underground water resources. Such indices are adapted from the US National Sanitation Foundation Water Quality Index, NSFWQI, Brown et al. [46] to define national-level water quality standards of Iran. The Department of Environmental Protection of Iran recommended this WQI for the evaluation of the quality of the surface and underground water resources of the territory [47]. We use such indices for quantitative expressions of the quality of collected water through RWH systems. The index calculates for a batch of sampled values of $M$ water quality parameters as:

$$
\text { IRWQI }=\sum_{i=1}^{M}\left(I_{i} w_{i}\right)^{\frac{1}{a}} \text { with } a=\sum_{i=1}^{M} w_{i}
$$

where $I_{i}$ and $w_{i}$ respectively are sub-index and assigned weight of the $i$-th water quality parameter. The index of IRWQI can separately be evaluated for conventional water quality properties (IRWQI $I_{S C}$ ) or toxic (IRWQI $I_{T C}$ ) pollutions. With the scope of the present study, we evaluated both IRWQI ${ }_{S C}$ and IRWQI $I_{T C}$ for sampled measurement values obtained for a set of water quality parameters listed in Table 2 . Notes that $8.26 \mathrm{mg} / \mathrm{L}$ of dissolved oxygen provides $100 \%$ DO saturation. For the sampled value of the $i$ parameter, sub-index of $I_{i}$ can be extracted from Figure 1. 
Table 2. Selected parameters and the related weights for the assessment of conventional water quality and toxic pollution of the harvesting water.

\begin{tabular}{ccc}
\hline Title 1 & Parameter & Weight \\
\hline & BOD $_{5}(\mathrm{mg} / \mathrm{L})$ & 0.117 \\
COD $(\mathrm{mg} / \mathrm{L})$ & 0.093 \\
Conventional Pollutants & DO Saturation, $\%$ & 0.097 \\
& Electrical conductivity $(\mu \mathrm{S} / \mathrm{cm})$ & 0.096 \\
& Fecal Coliform $(\# / 100 \mathrm{~mL})$ & 0.14 \\
& TH $(\mathrm{mg} / \mathrm{L})$ & 0 \\
& Turbidity $(\mathrm{NTU})$ & 0.062 \\
$\mathrm{pH}$ & 0.051 \\
\hline Toxic Pollutants & Lead $(\mathrm{Pb}), \mathrm{ppb}$ & 0.092 \\
& Cadmium $(\mathrm{Cd}), \mathrm{ppb}$ & 0.092 \\
& Chromium $(\mathrm{Cr}), \mathrm{ppb}$ & 0.084 \\
& BOD $_{5}(\mathrm{mg} / \mathrm{L})$ & 0.117 \\
\hline
\end{tabular}
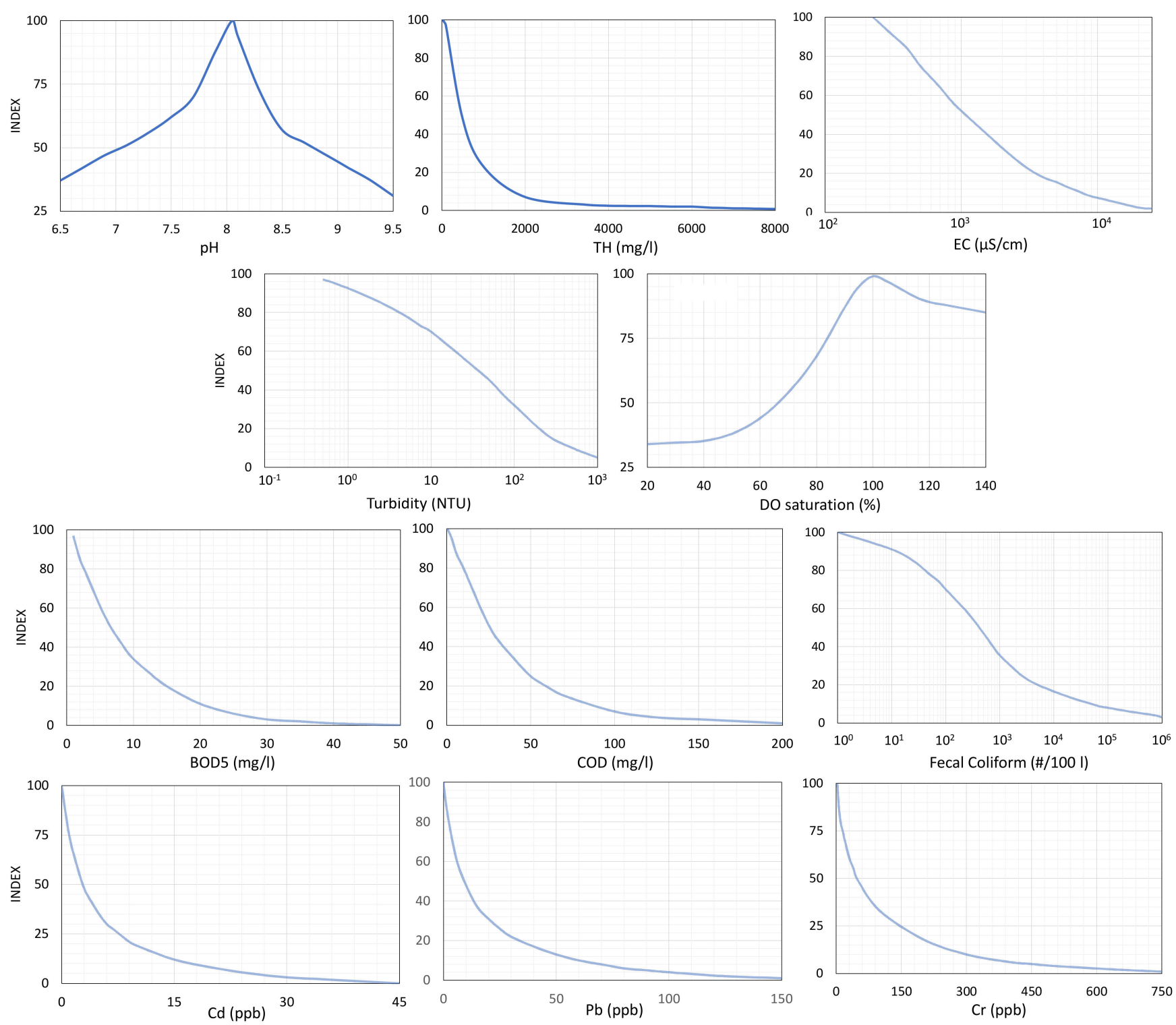

Figure 1. Evolution of sub-index values, $I_{i}$, with the value of $i$-th water quality parameter observed in the RWH system. 
When IRWQI is evaluated from Equation (5), we can classify quality of the analyzed surface/underground water resource according to Table 3. Here, the 100-score scale of IRWQI is divided into 7 classes (see Table 3) of water quality, and different colors are assigned to each class for illustrative purposes.

Table 3. Color bar specifying ranges of IRWQI for different water quality classes of Management IWR [42] standard, reflecting quality of a surface/underground water resource.

\begin{tabular}{cccccccc}
\hline IRWQI & $\mathbf{0 - 1 5}$ & $\mathbf{1 5 - 3 0}$ & $\mathbf{3 0 - 4 5}$ & $\mathbf{4 5 - 5 5}$ & $\mathbf{5 5 - 7 0}$ & $\mathbf{7 0 - 8 5}$ & $\mathbf{8 5 - 1 0 0}$ \\
\hline Description & Unfitted & Poor & Almost poor & Moderate & Almost good & good & Excellent \\
\hline
\end{tabular}

\section{Results}

Results of our analysis are structured across the following. Section 3.1 includes a concise introduction of climate and hydrologic elements related to the studied region, as well as the pilot RWH system. Results of preliminary stochastic analyses performed on the collected dataset are summarized in Section 3.2. We assess the overall quality of the harvested water in Section 3.3. We discuss the feasibility of using the harvested water for diverse consumption purposes by evaluating its chemical and biological quality in comparison with the water quality standards and regulations illustrated in Section 2.2.

\subsection{Pilot RWH System}

To promote using RWH against water shortage in Mashhad city, three sites were selected and equipped to represent three types of catchments that are typical for rainwater harvesting (see [12] for details). We provide here characteristics and performance of a pilot project that has been equipped in two hectares campus catchment, including a network of access roads, parking space, and green lands inside KANRRC (Figure 2c).

We first report climatical and hydrological conditions of the studying region. Mashhad is located in northeast of Iran (longitude of $59^{\circ} 38^{\prime}$, latitude of $36^{\circ} 16^{\prime}$, and elevation of $999.2 \mathrm{~m}$ ) surrounded by Binalood and Hezarmasjed mountains (Figure 2a). Mashhad is the second most populous city of Iran and takes the importance from its agricultural, industrial, and touristic destination values [48]. The urban structure of the city has been extensively developed to the northeastern parts since 1890s (see Figure 2b). The population of Mashhad was reported to be roughly six hundred thousand inhabitants in 1986, and it has increased by six folds since 2010. The city attracted more than 20 million annual visitors in 2010. Such an ascending trend of residential and touristic population in Mashhad city has provided an economic boom in recent decades; hence, simultaneous improvements of urban services is a requisite [48]. The city attracts higher number of visitors in the period of March to August, which is mainly concentrated in hot-dry seasons of the year and coincides with the peak of water demands.

Water supply in Mashhad is a serious issue for the municipality. Groundwater is the major source of water supply, which is facing severe depletions of the aquifers mainly due to agricultural uses. The surrounding area of Mashhad metropolitan is covered by cultivated fields. Overexploitation of groundwater from pumping wells to provide water for the agricultural activities has lowered aquifer hydraulic heads and caused subsidence in large rural areas [49].

According to the data acquired during past 30-year period, the mean annual temperature of the Mashhad subbasin is an estimated $12.5^{\circ} \mathrm{C}$, and the average amount of annual rainfall is evaluated as 315 and $258 \mathrm{~mm}$ in mountainous and plain areas, respectively. Rainfall mainly occurs in spring and winter seasons; however, the aquifer does not receive sufficient recharge, resulting in a continuous decrease of groundwater level. Accordingly, land subsidence due to excessive groundwater extraction has occurred over the years. Alizadeh [50] reported that there has been average decrease in groundwater table of $12 \mathrm{~m}$ in Mashhad subbasin during 15 years. 


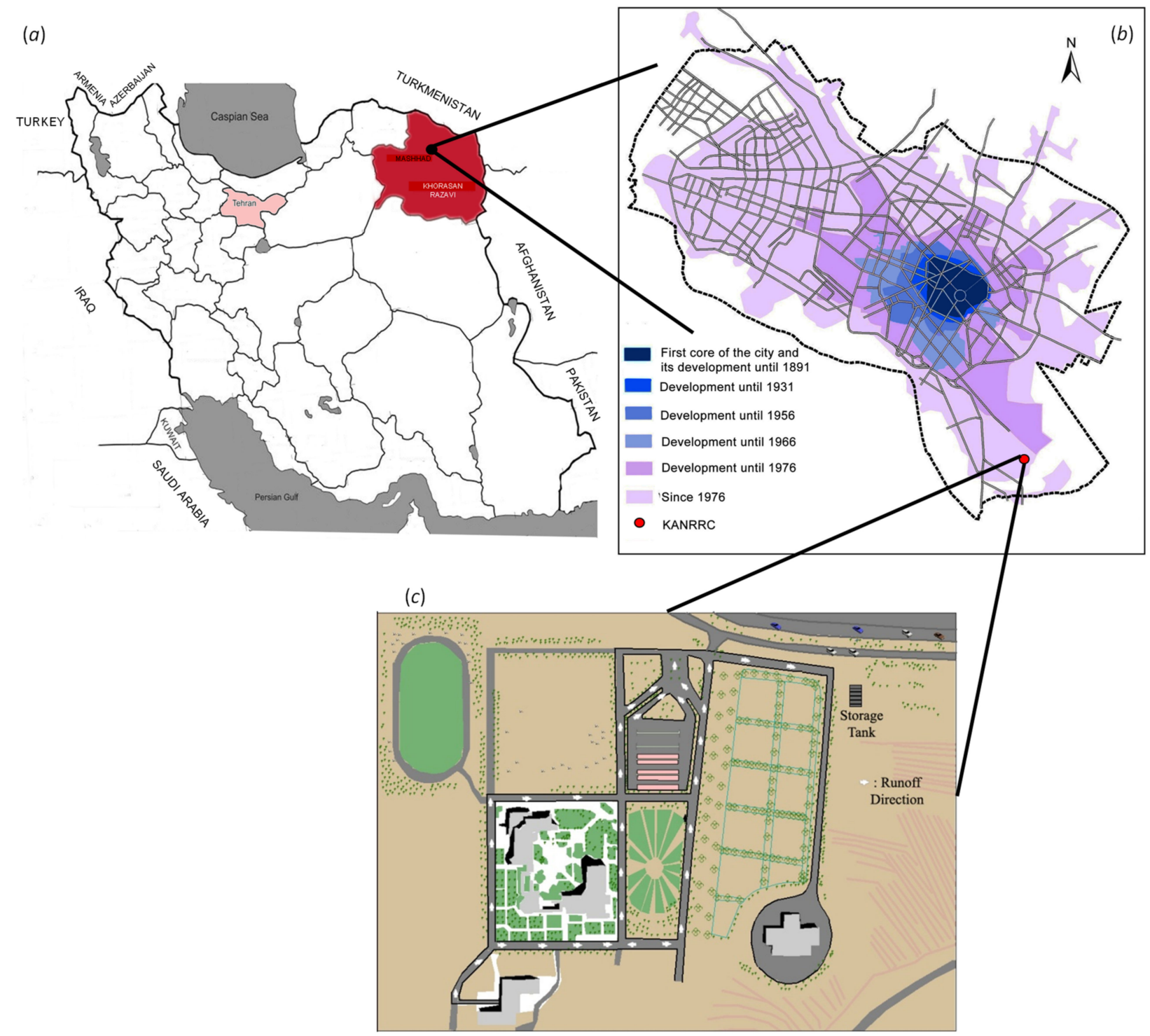

Figure 2. (a) Location of Mashhad city in Iran, (b) urban structure and development of Mashhad city since 1890s, and (c) schematics of the pilot RWH catchment and runoff direction across urban surfaces to the storage tank.

We applied the Emberger [51] technique (see Appendix A) to evaluate climate conditions of our study region by referring to three important climatical elements of (i) precipitation, (ii) temperature, and (iii) evaporation. Our assessment of the long-term climatical observation confirms that (i) maximum and minimum (long-term monthly averaged) range of temperature are respectively equal to -3.8 and $34.4{ }^{\circ} \mathrm{C}$; (ii) temperature is approximately 60 days (per year) under zero centigrade degree (typically happening in the period of December to March), (iii) the region has roughly 70 annual rainy days, while more than $90 \%$ of all rainfall events happen with the depth of $10 \mathrm{~mm}$ or less; (iv) mean annual rainfall depth is estimated as $251 \mathrm{~mm}$, with seasonal rainfall depths of 49.5, 123.5, 78.4, and $3.5 \mathrm{~mm}$ during autumn, winter, spring, and summer, respectively, and (v) annual evapotranspiration is equal to $1400 \mathrm{~mm}$. Accordingly, we evaluated Emberger coefficient $I_{E}=22$ and categorized the climate of Mashhad as cold and dry (semiarid). In these circumstances, attention to the modern water resources management techniques is currently increasing among experts.

To establish a drainage basin of RWH, (a) the catchment landscape should guarantee readily generations of rainfall-runoff, (b) the topography must allow concentration of the runoff flow in some pre-decided parts of the landscape, and (c) the storage points must have 
sufficiently deep soils of suitable texture and structure to retain the runoff water received. Our pilot project collected generated runoff from about $5000 \mathrm{~m}^{2}$ asphalted road and parking, which drained off the building and wasted in the city sewer system. We blocked the sewer intake gate and diverted collecting runoff (through a newly constructed channel) into an underground reservoir. Figure $2 \mathrm{c}$ depicts the RWH drainage basin and direction of drained water flow to the $1200 \mathrm{~m}^{3}$ storage tank. Generated runoff from rainfall events passes through a small desilting basin the ground reservoir tank. The capacity of the tank is decided based on hydrological analysis of the studying basin.

We used Kirpich [52] formula (see Appendix B), which was originally developed for small drainage basins, and estimated time of concentration, $t_{c}$, according to the Equation (A2) for our studying catchment. Based on physiographic (GSI-based) analysis of the drainage basin, we calculated total runoff area of $19,000 \mathrm{~m}^{2}$, longest basin length of $700 \mathrm{~m}$, and mean basin slope of $3.6 \%$. We calculated $t_{c}$ for our test case basin equal to $5 \mathrm{~min}$ (for runoff through the surfaces covered by asphalt). This value is relatively a short time of concentration. Accordingly, a long-duration rainfall event may create a collocation of divided runoff happenings. Therefore, we analyzed a rainfall of more than one day duration as a set of some smaller rainfall events. The rainfall-runoff relationship was characterized through Equations (A2) and (A3). A total number of 75 rainfall happenings were recorded in situ for two years (i.e., 2008 and 2009), and almost $30 \%$ of the total rainfall events led to the creation of a sufficient runoff. Figure 3a reports intensity and duration time of the rainfall events that created runoff to charge our RWH system. The creation of runoff was evaluated by Equation (A3) when $P$ was almost $20 \%$ of maximum storage depth, $D$, Refs. [53,54] and $C N$ was set to 95 [55]. Our analysis of rainfall-runoff events satisfies that a rainfall with a minimum depth of $2.2 \mathrm{~mm}$ (intensity of $8.6 \mathrm{~mm} / \mathrm{h}$ and duration of $0.25 \mathrm{~h}$ ) can result a sufficient runoff for our RWH system. Figure $3 \mathrm{~b}$ illustrates rainfall depth and the resulting estimations of runoff. Results are reported for selected rain events that can create runoff to charge the RWH system.

Our pilot RWH project takes a relevant role in collecting generated runoff from almost $5000 \mathrm{~m}^{2}$ asphalted road and parking, which has been previously drained off (and wasted) through the centralized city sewer system. We controlled the sewer intake gate to divert collecting runoff (through a constructed channel) into the RWH system up to reaching dewater capacity of the storage reservoir. Accordingly, not only collecting rainwater through the RWH project can stand as a supplementary source of water storage in rainy seasons and supply it for further uses in hot-dry seasons, but also it can potentially play a relevant role in stormwater management.

\subsection{Data-Driven Stocastic Analysis}

We obtained some samples of water from the RWH system and determined their physicochemical properties (i.e., acidity in terms of potential of hydrogen, $\mathrm{PH}$, total hardness, TH, total dissolved solids, TDS, electrical conductivity, EC, and sodium content, $\mathrm{Na}$, of water), according to the standard methods [56,57]. Water samples were obtained in various conditions of time (before, during, and after rainfall events) and place (in a sedimentary at the outlet of drainage catchment and the reservoir tank). A total of 35 sampling measurements were collected (in a $500 \mathrm{~mL}$ sterilized bottle) for two years, at the outlet of the drainage basin as well as inside the storage tank.

We performed some preliminary stochastic analysis to the physicochemical properties of the sampled water. Figure 4 depicts box-plot representations of the variability of the samples of target state variables (including TH, TDS, $\mathrm{Na}, \mathrm{pH}$, and EC). All data points are rescaled here and normalized to the unit interval [0,1], for ease of comparison. Most of the observation values of the water quality parameters of TH, TDS, Na, and EC are concentrated between the 25th and the 75th percentile of the corresponding distributions. Observed values of $\mathrm{pH}$ exhibit a few notable numbers of (high valued) outliers, the highest (normalized) value of the observation still within 1.5 of the interquartile range (IQR), with the upper quartile being 0.38 . 


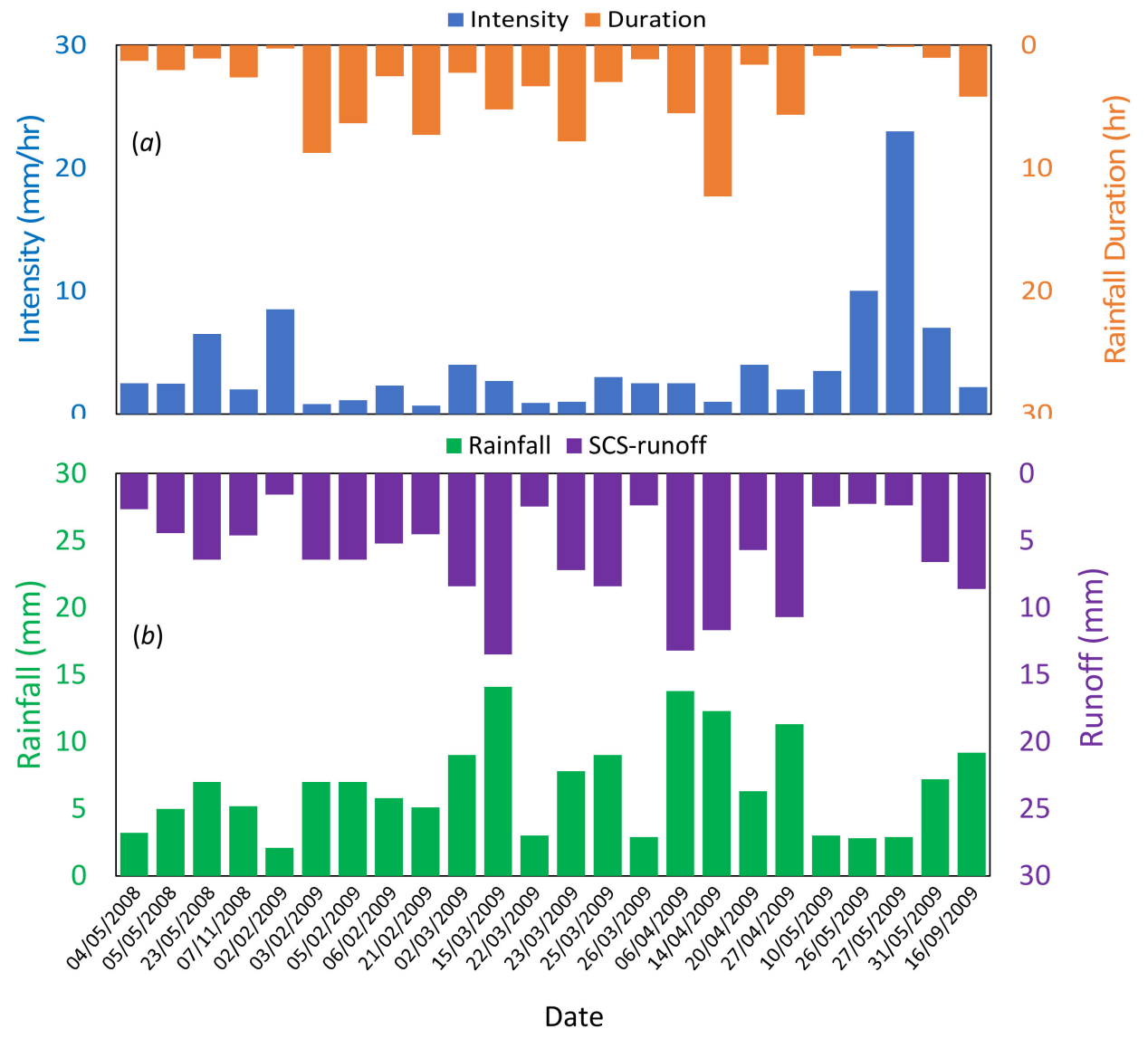

Figure 3. Intensity duration time (a) and depth of the rainfall events (b), as well as the related creation of runoff.

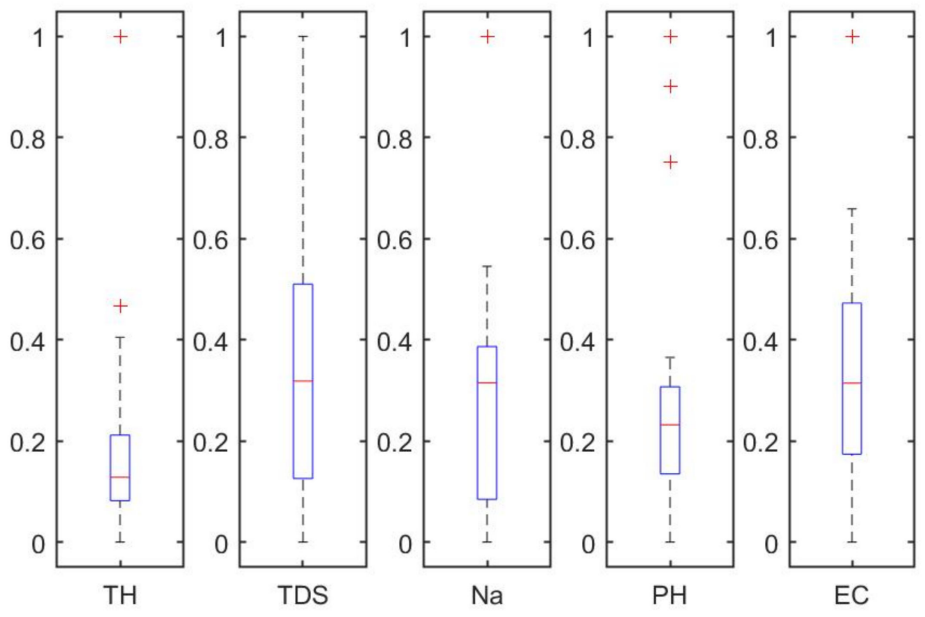

Figure 4. Box-plot representation of the variability of state variables $\left(X_{1}-X_{5}\right)$. Each box-plot identifies 25th, 50th (median), and 75th percentile scores. Whiskers correspond to the lowest observation within 1.5 of the interquartile range (IQR) of the lower quartile and to the highest observation still within $1.5 \mathrm{IQR}$ of the upper quartile; crosses represent outliers.

Analysis of the bivariate correlation among the system performance variables (see Figure 5) suggests that (i) the highest degree of correlation can be noted between EC and TH, TDS, and $\mathrm{Na}$, as denoted by values of the correlation coefficient equal to 0.6 , 0.7 , and 0.55 , respectively; (ii) $\mathrm{pH}$ shows some correlations with $\mathrm{Na}$ (coefficient of 0.3), meanwhile appears to have negligible correlations with EC, TH, and TDS (with values of the correlation coefficient equal to $-0.15,-0.12$, and -0.07 ); and (iii) moderate correlations 
recognized between $\mathrm{TH}$, with both TDS, and $\mathrm{Na}$ (with 0.37 and 0.42 correlation coefficients). These results are confirmed by analyzing bivariate scatter plots of the sampling (normalized) values as presented in Figure 6. An almost linear evolution of the sampling values of EC with the values of TH, TDS, and Na parameters is satisfying from a physicochemical point of view (see [58]).

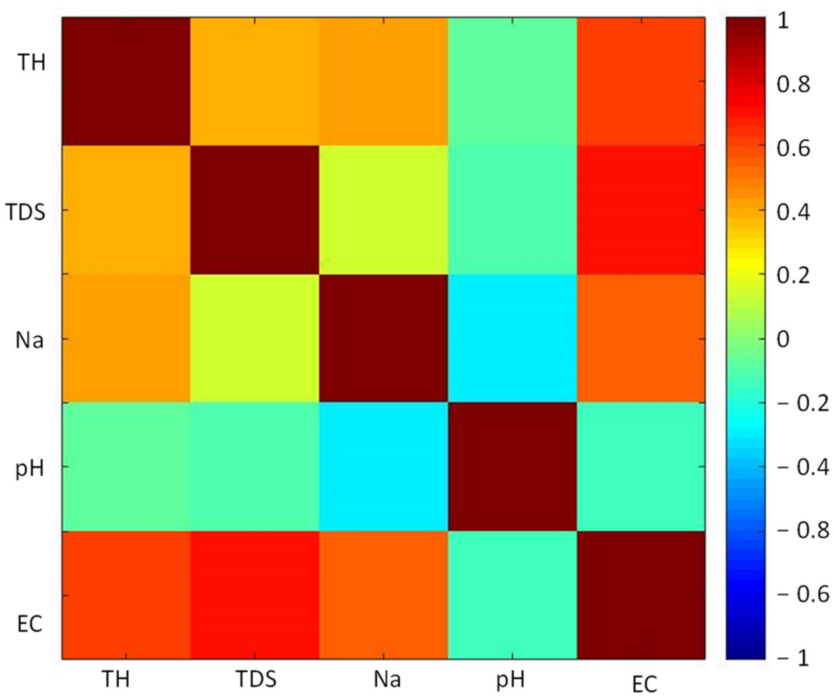

Figure 5. Bivariate correlation between experimental sample data included in matrix $\boldsymbol{X}^{*}$.
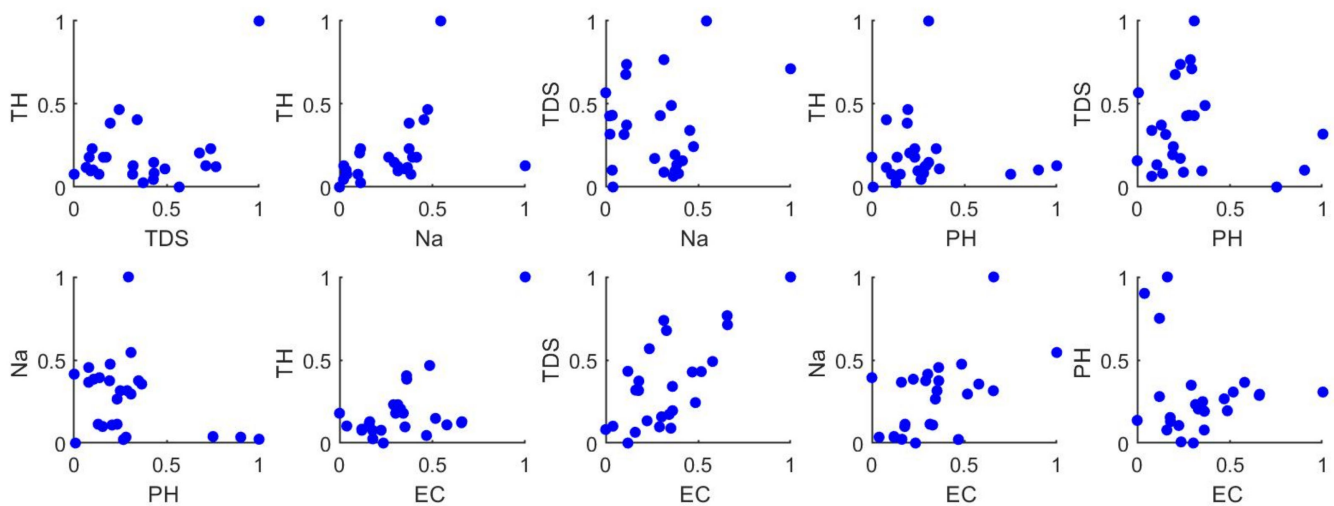

Figure 6. Bivariate scatter plots of the sampling (normalized) values obtained for some physicochemical water quality properties of the harvested water.

We performed PCA-based clustering of the collected measurements. Figure 7 depicts the results of the PCA analysis. The complete set of principal components is in principle as large as the original set of considered physicochemical parameters (see Figure 7a). A general criterion to establish when a given set of principal components provides a satisfactory representation of the full variability of the dataset $X^{*}$ is not available [59]. However, typically, a percentage larger than $70 \%$ is deemed sufficient to grasp the main features of the original data. Figure 7a shows the percentage of the total variance of the output explained by each principal component and suggests that more than $72 \%$ of the variance of $\boldsymbol{X}^{*}$ is explained by considering only the first two principal components. Figure $7 \mathrm{~b}$ represents the projection of the sampled water quality parameter values onto the space of the first two linear PCs together with the vectors of coefficients of each water quality parameter in the PCs reference system. Figure $7 \mathrm{~b}$ shows that the vectors representing the variables TH, TDS, and EC have higher contributions to the direction identified by the first principal component, PC1. This result suggests that these variables are associated with a considerable portion of the variability of the dataset, as PC1 explains $50 \%$ of the total 
variance of $\boldsymbol{X}^{*}$ (see Figure 7a). The vector identifying $\mathrm{pH}$ is mainly aligned with the second principal component PC2. Variation of Na similarly contributes in both PC1 and PC2. This latter result is in agreement with the previously discussed results of Figures 5 and 6.
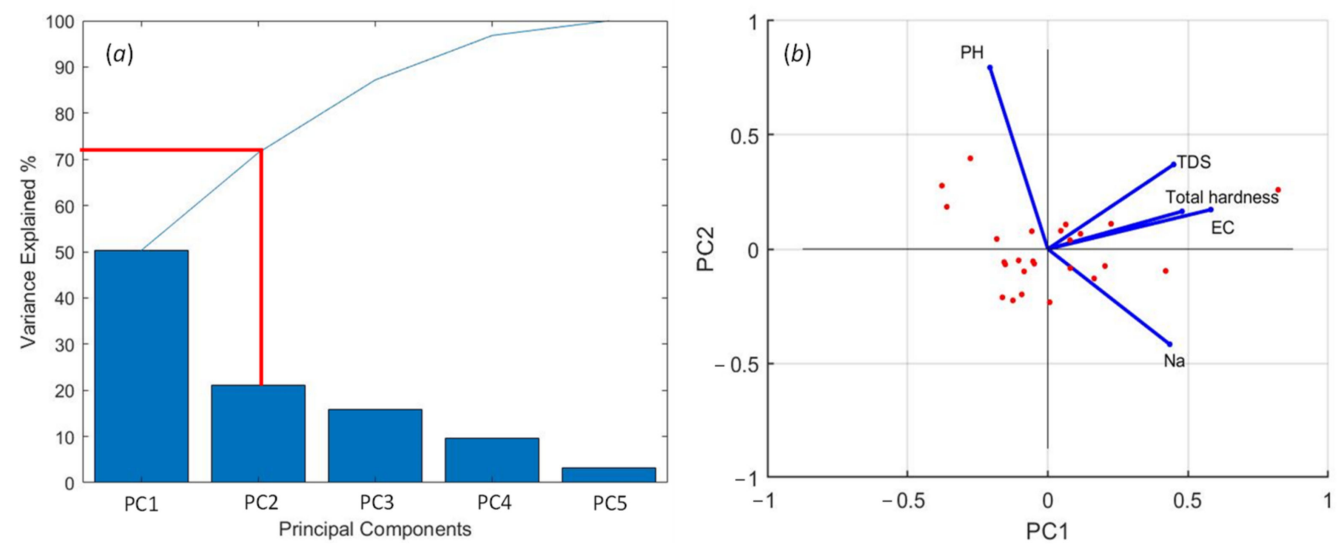

Figure 7. Result of linear PCA: (a) percentage of the total variance of $X^{*}$ described by the five principal components (PCs); projection of the measurements onto the plane of first two principal components, PC1 and PC2. Arrows in (b) indicate the vectors of PC coefficients associated with the original water quality parameters in the PCs space.

The water quality dataset (projected to the principal components) was then subjected to the k-means clustering; aiming to determine the best number of clusters for classifying the collected dataset. Determining the ideal number of clusters for k-means clustering can be done by measuring the mean of Silhouette indices, $I_{S}$, calculated from Equation (4). Figure 8a illustrates the increase of $I_{S j}$ as a function of the number of clusters. We decided to cluster the collected dataset into two groups as the increase of $I_{S j}$ with a higher number of groups was relatively mild. Figure $8 \mathrm{~b}$ illustrates $I_{S j}$ calculated for observation points when they are clustered in two groups. Results of categorization seems reasonable while most values of Silhouette indices take positive values (higher than 0.4).

We juxtaposed results of k-mean clustering of water quality sampling data in two clusters (Figure 8c) and projected the measurements obtained in the drainage basin and the ones collected in the RWH reservoir, separately, into principal coordinate systems (Figure 8d). Behavioral similarity of these two plots indicates that the quality of the water samples collected in the drainage catchment may be different from that of the samples obtained in the RWH reservoir.

Figure 9 depicts distributions (i.e., sample $p d f$ ) of the sampled values of water quality parameters rendered separately for observations collected in drainage basin and the ones obtained in the RWH reservoir. Results generally show that measurements of TH, TDS, $\mathrm{Na}$, and $\mathrm{pH}$ sampled in the reservoir are more concentrated around the mean values (with higher pick values of $p d f$ ) when comparing to the ones collected inside the drainage basin. Sample $p d f$ of $\mathrm{TH}$ and $\mathrm{pH}$ exhibits some similar behaviors for the measurements obtained from the catchment and those obtained from the reservoir.

We noticed that the distribution of $\mathrm{pH}, \mathrm{TH}$, and Na values obtained in the drainage basin exhibits long tails to the higher values, when comparing the $p d f$ of the same parameters for sampling values obtained from the reservoir, which concentrate around smaller values. Measurement records of $\mathrm{Na}$ collected from different places are associated with a completely different $p d f$. While values of $\mathrm{Na}$ content of the water in the drainage catchment show higher variations (in the range of 0 to $70 \mathrm{mg} / \mathrm{L}$ ), sampled values of $\mathrm{Na}$ from stored water in the reservoir vary in a more limited range (of $20-30 \mathrm{mg} / \mathrm{L}$ ). This is an interesting outcome that the quality of the stored water in the RWH reservoir is more stable than that obtained for rainfall-runoff events. This can be linked to the heterogeneity of the characteristics of the drainage basin and supply conditions of the reservoir. 

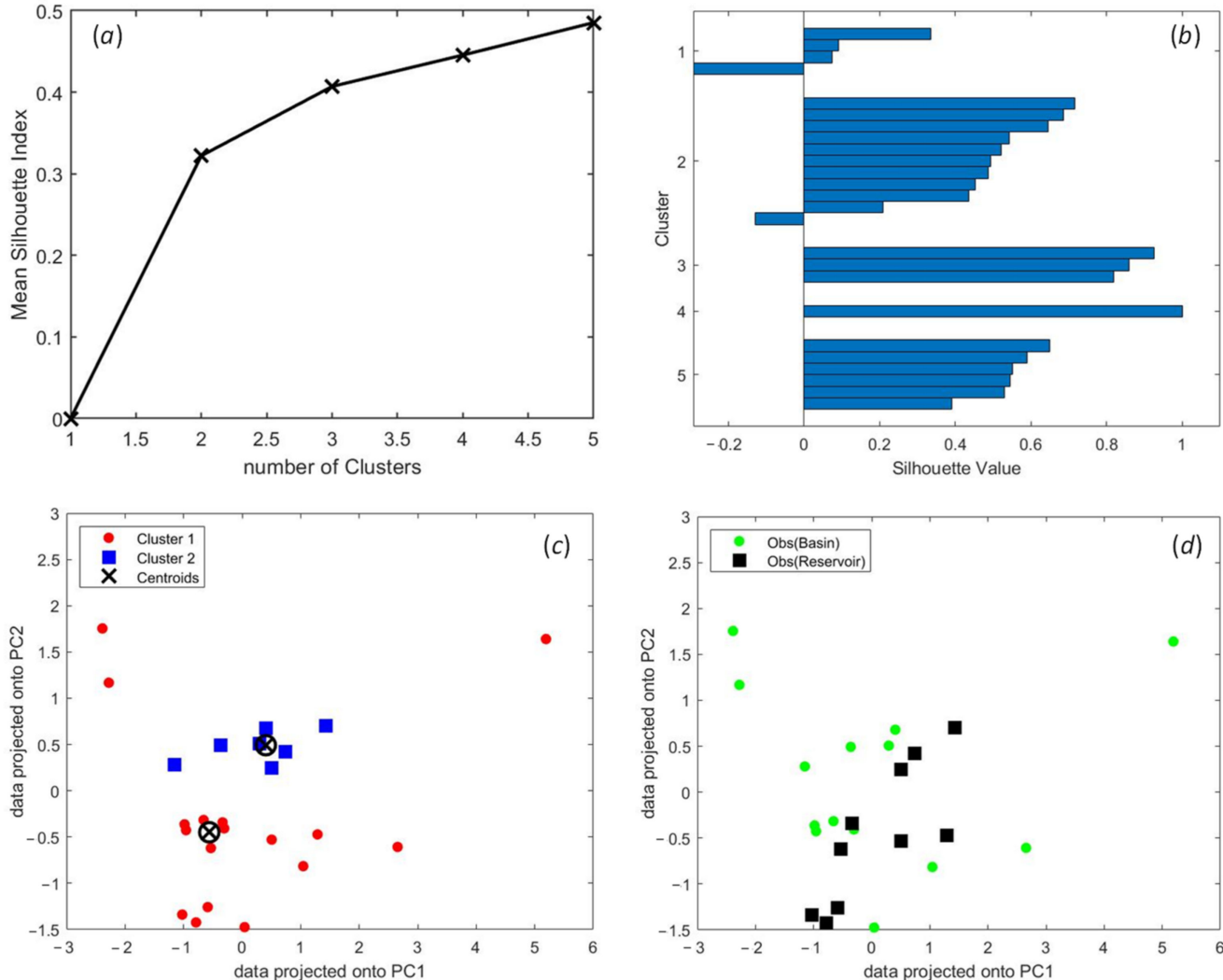

Figure 8. K-mean clustering results: (a) evolution of Silhouette indices with the number of clusters, (b) Silhouette indices calculated for each observation point while clustering measurements into two categories, (c) water quality sampling data (in principal component space) clustered in two groups, (d) original measurements obtained in drainage basin and the ones collected in the reservoir projected (separately) into principal coordinate systems.
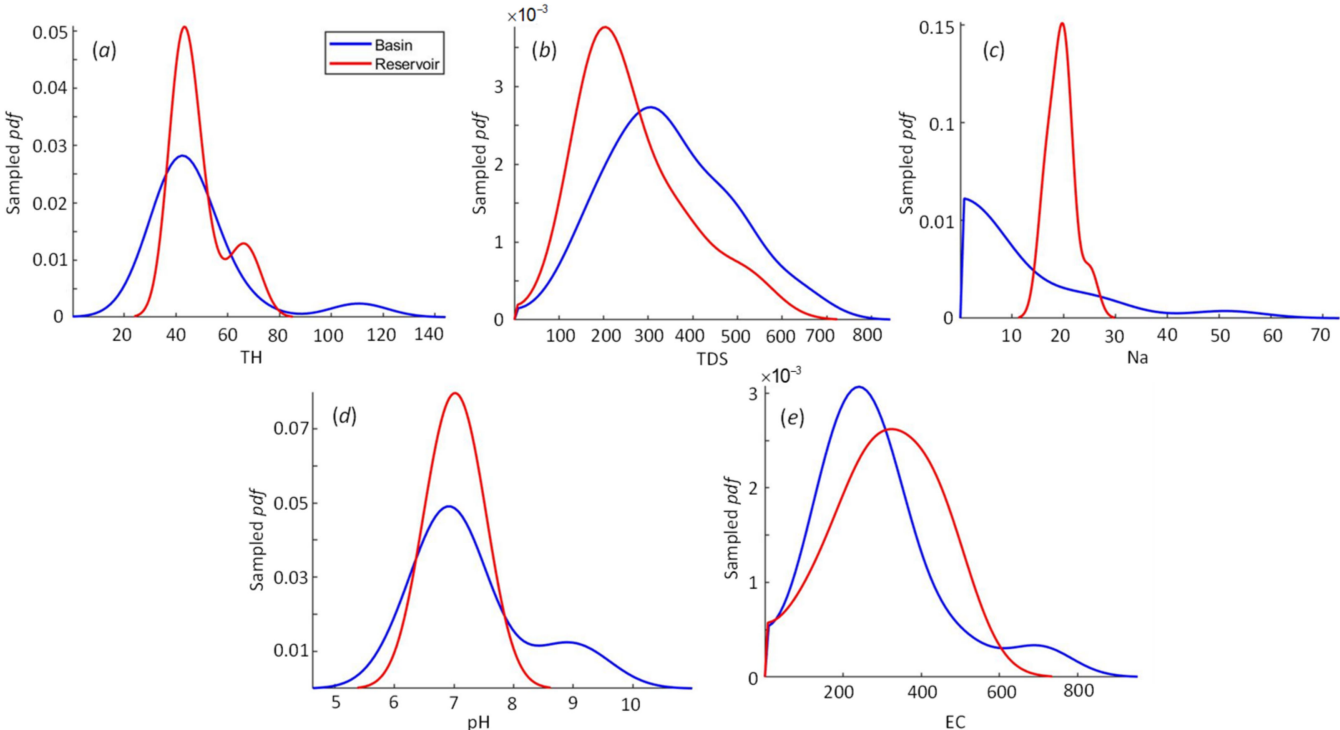

Figure 9. Distributions of the observed values of water quality parameters. The sampled $p d f$ is reported separately for the measurements recorded in the outlet of drainage catchment and those recorded in the RWH reservoir.

\subsection{Water Quality Assessment}

Water samples were subjected to the analyses of some key physicochemical and microbiological water quality tests. Following, we provide an assessment of the collected 
information. Table 4 reports assessment of water quality measurements in view of the guidelines (see Table 1) of the selected standards for different consumption uses. Results generally confirm that the mean observed values of samples from harvested water satisfy the needs of all considered standards in terms of $\mathrm{pH}$, Th, TDS, and Na. Chemical processes generally can take place at a certain range of acidity or basicity conditions. A key use of $\mathrm{pH}$ tests in water analysis is for detecting abnormal water quality. Values of $\mathrm{pH}$ outside the normal range need further attention, as water may contain toxic properties that may (i) cause nutritional imbalance for aquatic organisms and/or (ii) affect the solubility of water. We observed three sampling data (obtained from drainage basin within the beginning of the rain events) with $\mathrm{pH}$ values in the range of $8.5-9$, hence all samples of water from the reservoir satisfy the $\mathrm{pH}$ of soft water. Observations of $\mathrm{TH}$ also satisfy suggestions of considered guidelines for drinking, irrigation, and surface water (to be used for drinking, irrigation, or from environmental concerning points) quality. Sodium content of the samples was in the range of 1 to $50 \mathrm{mg} / \mathrm{L}$, which satisfies all needed standards. An acceptable condition was observed for TDS contaminant of the water samples. We measured a single sample with TDS value of $630 \mathrm{mg} / \mathrm{L}$ (observed in drainage basin at the beginning of a rain event), which is outside the maximum acceptable standard for drinking water, but satisfies regulations for other considered uses. We should note that TDS is an indicator of non-point source of pollution typically associated with problems of the land use conditions [60].

Table 4. Checklist of evaluating quality of the sampled water measurements with respect to the suggestions of the selected standards of different consumption uses.

\begin{tabular}{|c|c|c|c|c|c|c|c|c|}
\hline \multirow{2}{*}{\multicolumn{2}{|c|}{$\begin{array}{c}\text { Water Quality } \\
\text { Parameters }\end{array}$}} & \multirow{2}{*}{ Mean } & \multirow{2}{*}{ Std } & \multicolumn{2}{|c|}{ International Guidelines } & \multicolumn{3}{|c|}{ National Standards of Surface Water } \\
\hline & & & & $S_{1}$ & $S_{2}$ & $S_{3}$ & $\mathrm{~S}_{4}$ & $\mathrm{~S}_{5}$ \\
\hline \multicolumn{2}{|l|}{$\mathrm{PH}$} & 7.2 & 0.7 & $\checkmark$ & $\checkmark$ & $\checkmark$ & $\checkmark$ & $\checkmark$ \\
\hline \multicolumn{2}{|c|}{$\mathrm{TH}(\mathrm{mg} / \mathrm{L})$} & 48.4 & 15.7 & $\checkmark$ & $\checkmark$ & $\checkmark$ & $\checkmark$ & $\checkmark$ \\
\hline \multicolumn{2}{|c|}{ TDS (mg/L) } & 315 & 131 & $\checkmark$ & $\checkmark$ & $\checkmark$ & $\checkmark$ & $\checkmark$ \\
\hline \multicolumn{2}{|c|}{$\mathrm{EC}(\mu \mathrm{S} / \mathrm{cm})$} & 300 & 137 & $x$ & $\checkmark$ & $\checkmark$ & $\checkmark$ & $\checkmark$ \\
\hline \multicolumn{2}{|c|}{ Total Coliforms (\#/100 mL) } & 800 & - & $x$ & $x$ & $X$ & $\checkmark$ & $\checkmark$ \\
\hline \multicolumn{2}{|c|}{ Fecal Coliforms (\#/100 mL) } & 110 & - & $x$ & $x$ & $X$ & $\checkmark$ & $\checkmark$ \\
\hline \multicolumn{2}{|c|}{$\mathrm{BOD}_{5}(\mathrm{mg} / \mathrm{L})$} & 25 & - & $x$ & $\checkmark$ & $X$ & $\checkmark$ & $\checkmark$ \\
\hline \multicolumn{2}{|c|}{$\mathrm{COD}(\mathrm{mg} / \mathrm{L})$} & 46 & - & $x$ & $\checkmark$ & $\checkmark$ & $\checkmark$ & $\checkmark$ \\
\hline \multicolumn{2}{|c|}{ Color (CU) } & 94 & - & $x$ & $\checkmark$ & $X$ & $\checkmark$ & $\checkmark$ \\
\hline \multicolumn{2}{|c|}{ Turbidity (NTU) } & 16 & - & $x$ & $\checkmark$ & $\checkmark$ & $\checkmark$ & $\checkmark$ \\
\hline \multicolumn{2}{|c|}{$\mathrm{DO}(\mathrm{mg} / \mathrm{L})$} & 4 & - & $x$ & $\checkmark$ & $X$ & $\checkmark$ & $\checkmark$ \\
\hline \multicolumn{2}{|c|}{$\mathrm{Na}(\mathrm{mg} / \mathrm{L})$} & 15.08 & 11.38 & $\checkmark$ & $\checkmark$ & $\checkmark$ & $\checkmark$ & $\checkmark$ \\
\hline \multirow{4}{*}{$\begin{array}{c}\text { Heavy Metals } \\
\quad(\mathrm{ppb})\end{array}$} & $\mathrm{Pb}$ & $<1$ & - & $\checkmark$ & $\checkmark$ & $\checkmark$ & $\checkmark$ & $\checkmark$ \\
\hline & $\mathrm{Cd}$ & $<1$ & - & $\checkmark$ & $\checkmark$ & $\checkmark$ & $\checkmark$ & $\checkmark$ \\
\hline & $\mathrm{Ni}$ & $<1$ & - & $\checkmark$ & $\checkmark$ & $\checkmark$ & $\checkmark$ & $\checkmark$ \\
\hline & $\mathrm{Cr}$ & 100 & - & $x$ & $x$ & $X$ & $\checkmark$ & $\checkmark$ \\
\hline
\end{tabular}

The mean value of EC observations is at the higher bound of the WHO $\left(\mathrm{S}_{1}\right)$ drinking water standard ( $30 \%$ of measurements are out of the range), hence all sampling values lie in an acceptable range of regulations for other uses. Water with greater ions contamination has higher EC. Instead, low-salinity water (i.e., EC $<200 \mu \mathrm{S} / \mathrm{cm}$ ) may have $\mathrm{pH}$ outside the normal range since it has a very low buffering capacity. Such water can lead to some problems for soils and crops. It is also very corrosive for pipelines, sprinklers, and control irrigation equipment.

In addition, we assessed the quality of the collected water in the reservoir tank (dated to the end of October 2010) for biological (including color, turbidity, dissolved oxygen, DO, biochemical oxygen demand, $\mathrm{BOD}_{5}$, chemical oxygen demand, $\mathrm{COD}$, number of total and fecal coliforms in $100 \mathrm{~mL}$ of water) contaminants as well as toxic metals heavy (lead, $\mathrm{Pb}$, nickel, $\mathrm{Ni}$, cadmium, $\mathrm{Cd}$, and chromium, $\mathrm{Cr}$ ) pollutants.

The color of the sampled water is just at the upper convenient limit of drinking water. The relatively clarity of the collected water can be linked to the fact that our urban 
RWH system has small basins (as typical) including constructed (asphalted or concreted) roadbeds and floors. Accordingly, runoff creation has a small time of concentration (5 min in our case). Turbidity represents the amount of solid particles suspended in collected water. It is a measure of the light-scattering properties of water, which can be in the form of minerals or organic matters. The turbidity of the water obviously makes it unacceptable for drinking (according to WHO guidelines), but it is appropriate as a surface water that can be used after filtration and/or refinements (referring to guidelines of $S_{3}$ ), even for drinking. Similar results are reported in terms of COD. The COD is the estimate of oxygen required for the portion of organic matter in water/wastewater that is subjected to oxidation. Then, COD is a measure of oxygen demand of organic matters in water/wastewater; accordingly, it not only determines the amount of biologically active substances such as bacteria but also biologically inactive organic matter in water. Our observations show that the COD level of water collected from our domestic RWH system is much lower than that expected from a centralized system of urban-generated wastewater [61]. BOD, instead, represents the amount of oxygen consumed by bacteria and other microorganisms while they decompose organic matter under aerobic (i.e., in presence of oxygen) conditions at a specified temperature. Measurements of BOD obtained over a period of five days (i.e., $\mathrm{BOD}_{5}$ ) confirm the quality of the collected water for agricultural uses and from the environmental concerning point. The DO property of the sampled water makes it convenient for any predefined usage of Table 4, except drinking consumption. DO is critical component for survival of various aquatic lives in streams, especially for environmental concerns. The ability of water to hold solution of oxygen is inversely proportional to the temperature of the water. Usually, the higher the amount of organic material found in the stream, the more oxygen that is used for aerobic oxidation [62], which can deplete the amount of BOD available to other aquatic life.

Heavy metals may occur (even naturally) in an aqueous ecosystem with large variations of concentration [63]. Some of them are dangerous to health (like cadmium, lead, and chromium), and some (e.g., lead) may cause corrosion of the irrigation equipment. Toxic pollution of water with heavy metals is more concerning in urban water draining basins, where water is prone to be polluted by waste-derived fuels. Our observations show satisfying contamination of water by $\mathrm{Pb}, \mathrm{Cd}$, and $\mathrm{Ni}$ (less than $1 \mathrm{ppb}=0.001 \mathrm{mg} / \mathrm{L}$ ). Nevertheless, the collected water contains $100 \mathrm{ppb}$ of $\mathrm{Cr}$ compound, which is out of the limit of water quality for drinking consumption as well as the one suggested for surface water to be used for drinking (after simple purifications).

Chromium does not occur freely in nature. The element and its compounds can be discharged in surface water through various activities and land uses. For example, chromium compounds are applied as pigments, and chromium in water may originate from painting. Stainless steel also consists of roughly $15 \%$ chromium. Chromium may also exist in domestic waste of various synthetic materials. Therefore, $\mathrm{Cr}$ contamination of the harvested water may be reduced by paying more attention to the land use of the draining basin.

Fecal coliform bacteria may indicate the presence of disease-carrying organisms that live in the same environment as the fecal coliform bacteria. The existence of coliforms (with total number of 800 and fecal number of 110 per liter of water) in our harvested water categorizes it out of the range of drinking water $\left(\mathrm{S}_{1}\right)$, even after performing infiltration and simple refinements $\left(\mathrm{S}_{3}\right)$. Hence, it lays inside the allowing range of national standards of surface water for agricultural consumptions $\left(\mathrm{S}_{4}\right)$ and environmental concerns $\left(\mathrm{S}_{5}\right)$.

We then evaluated IRWQI of Equation (5) to quantify the quality of the harvested water as a surface water (without performing any infiltration and treatment). The results categorize our collected water in the yellow to green condition of Table 3, indicating moderate conventional quality $\left(\mathrm{IRWQI}_{S C}=42.5\right)$ and almost good toxic quality $\left(\mathrm{IRWQI}_{S T}=61.6\right)$ of the harvested water.

To put it in a nutshell, we can confirm that collected water in our equipped $\mathrm{RWH}$ pilot does not meet some requirements of $\mathrm{WHO}$ guidelines for drinking water (see $S_{1}$ in 
Table 1) but it generally satisfies suggestions of FAO $\left(S_{2}\right)$ and national standards of surface water for environmental sustainability $\left(S_{5}\right)$ and the for irrigation uses $\left(S_{5}\right)$. The provided analysis confirms that this RWH system does not collect water for human consumptions. Consequently, we discourage the use of harvested water for domestic drinking water, unless performing special purifications, which are generally not economically convincing for domestic owners/users of small-scale RWH systems.

\section{Discussion and Concluding Remarks}

The present work has been conducted to evaluate the feasibility of rainwater harvesting and consumptions through installing small-scale RWH systems in an urban catchment, in Mashhad city. Our provided investigations categorize Mashhad city as a semiarid region where water scarcity is an inherent issue and high-intensity rainfalls (to generate sufficient runoff) rarely happen during hot-dry seasons. This issue synchronizes, annually, with increasing needs of drinking water for reasonably high numbers of touristic attractions to the city. The present work suggests RWH for compensating parts of seasonal water shortages in Mashhad city, which are repeatedly occurring due to current drought superimposed with soaring needs of water for agricultural, industrial, and drinking uses. Establishing a draining catchment of RWH in a semiarid urban area can be beneficial by storing water during rainy seasons and supplying it for further uses in hot-dry seasons. This can potentially play a relevant role in stormwater management, as well.

A pilot project was established inside KANRRC campus for collecting generated runoff from two-hectares catchment (including almost $5000 \mathrm{~m}^{2}$ asphalted road and parking), which has been previously drained off through the centralized city sewer system. Our analysis confirms that producing runoff can provide a sustainable source of water supply for crop cultivation and domestic gardening purposes.

Water quality assessment was performed by evaluating national water quality index (i.e., IRWQI). Sampling values of pH, Turbidity, DO, EC, TH, BOD 5 , COD, heavy metals (lead, cadmium, and chromium), and fecal coliforms have been measured. Some stochastic analyses were performed to the obtained values of water quality parameters. PCA-based k-mean clustering technique was applied to analyze the water quality dataset. The results show some relations of the place of sampling water (either inside drainage catchment or in the storing reservoir) with the quality of water. This can be linked to the characteristics of the drainage basin land use and supply conditions of the reservoir.

We used the collected dataset for the calculation of IRWQI. We evaluated IRWQI index, with 42.5 and 61.6 scores respectively for conventional and toxic pollution properties of the harvested water, and categorized such surface water resource as almost good quality.

Quality assessment of the collected water was performed with respect to some national and international guidelines for drinking, agricultural, and environmental water uses. Our findings confirm that the quality of the harvested water is generally inside the permission range of water quality standards suggested for irrigation uses and environmental concerns. Therefore, the collected rainwater can be used for domestic irrigation. Hence, harvested water needs some necessary treatments before supplying for drinking purposes. While previous works $[64,65]$ satisfy that the measured inorganic compounds in the harvested rainwater from roofyard catchment systems can match the international (e.g., [33]) guidelines for drinking water quality, our observations show that concentrations of some inorganic compounds in the rainwater collected from urban (e.g., asphalted and/or concreted) surfaces appear to be out of our considered national and international regulations of the drinking water quality. Disinfection should then be applied to improve the physicochemical and microbiological quality of water. In particular, using harvested water for drinking consumption (of human or livestock) requires performing infiltration and treatment to reduce $\mathrm{EC}, \mathrm{BOD}_{5}, \mathrm{COD}$, coliforms content, and heavy metal (i.e., $\mathrm{Cr}$ ) pollutants and improving DO properties of the collected water. 


\section{Recommendations}

The design and implementation of RWH projects need to be seriously considered in a water, energy, and food security nexus framework [66]. The assessment of a RWH project in developing countries typically focuses on the need of saving water, sometimes disregarding other benefits that might be related to a multipurpose nature of RWHs. These technologies are seen as sustainable options for adapting and (possibly) alleviating harmful impacts of climate change on water resources in arid/semiarid regions [67]. Local storage of rainwater during the wet season can provide a supplementary water reserve for intraseasonal drought periods, while potentially playing a relevant role in stormwater management practices [68]. Beneficial effects of RWH on mitigation of sewer overflow in the City of Toldeo are reported in [69]. Environmental impacts of RWH projects on hydrological systems are appraised in [70]. These authors suggest that RWH can play a relevant role in supporting regulation of the local hydrologic cycle. Infiltration of the harvested water is also documented to have positive impacts on aquifers. Watershed and local hydrologic impacts of RWH in India are analyzed in [71], also with reference to the use of RWH for groundwater recharge.

The development of strategies for water storage and recycling along circularity principles can clearly depend on the needs and goals of a given country [72]. For instance, per capita water use in the USA is about $4337 \mathrm{~L} /$ day, while being around $550 \mathrm{~L} /$ day in a Middle Eastern arid region like UAE [20]. Accordingly, various aspects associated with RWH projects need to be evaluated on a regional basis.

More than $90 \%$ of the allocated water in Iran was used for agricultural purposes in 2003 [66]. The total area of agricultural land has extensively increased since 1960, thus leading to an increase of agricultural water use from 44 billion $\mathrm{m}^{3}$ in 1961 to 86.5 billion $\mathrm{m}^{3}$ in 2011. Better coping with these elements can be achieved by relying on efficient RWH approaches, in line with recommendations stemming from our present work.

Rainwater collected from a RWH urban catchment may be polluted by, e.g., heavy metals. These pollutants may derive from vehicle tires and aliphatic hydrocarbons resulting from incomplete combustion processes. To attain drinking water quality (for human or livestock consumption), these hazardous compounds need to be removed from the harvested rainwater. Fecal pollution may also be present, originating from animals (e.g., birds, reptiles, and domestic livestock) that have access to the drainage catchments and/or a rainwater storage reservoir [29].

Furthermore, our observations show that the quality of the harvested water tends to improve with time during rainy seasons. We note that with the beginning of the rainy season, the first rainwater washes out most of the dirt, debris, contaminants, and animal feces accumulated in the system during dry seasons. A first-stage improvement of the harvested water quality can be achieved by flushing out early rainwater through the sewage system of the city. This can improve the quality of collected water and reduce RWH reservoir maintenance expenses. Additionally, collecting rainwater from building rooftops and storing it in protected tanks can alleviate the presence of toxic (heavy metal) contaminants in the harvested water for domestic drinking consumption uses [12]. A commonly used technique for disinfection and deactivation of microorganisms in the water is chlorination. Note that the latter should be performed after removal of the harvested rainwater from the storage reservoir/tank, to avoid chlorine reactions with organic matter settled at the bottom of the storage tank, leading to undesired quality effects [61]. Filtration (e.g., through sand filter) is also applicable in a modular way to remove hazardous substances from harvested rainwater [73]. Metal membrane filters are also suitable for purifications of collected rainwaters [74]. In this context, pasteurization by solar technology stands as a low-cost disinfection technique for water treatment [75]. Slow sand filtration (which relies on biological treatment rather than physical filtration processes) can also improve the biological quality of the water [76].

We can then note that, even as the results of the present study document the suitability of the harvested water for consumption/use (especially during a rainy period) when considering its quality in terms of inorganic substances, a comparison between biological 
quality aspects (including turbidity and color) of samples against available regulations of water quality suggests prioritizing the allocation of the harvested water for irrigation purposes. Collected rainwater from the RWH system is now set to be used for a botanic garden with the aid of a pressurized irrigation system.

Author Contributions: A.A.A. contributed to the design and implementation of the research, to the analysis of the results, and to the writing of the manuscript, J.T.Y. contributed to the design and implementation of the research, to the analysis of the results, and to the writing of the manuscript, M.Z. contributed to the design and implementation of the research, to the analysis of the results, and to the writing of the manuscript, E.R. contributed to the design and implementation of the research, to the analysis of the results, and to the writing of the manuscript. All authors have read and agreed to the published version of the manuscript.

Funding: This research received no external funding.

Institutional Review Board Statement: Not applicable.

Informed Consent Statement: Not applicable.

Data Availability Statement: Not applicable.

Acknowledgments: This work was partially supported by KANRRC.

Conflicts of Interest: Authors declare that they have no known competing financial interests or personal relationships that could have appeared to influence the work reported in this paper.

\section{Appendix A}

We refer to the Emberger [51] technique to evaluate climate conditions of our study region by referring to three important climatical elements of (i) precipitation, (ii) temperature, and (iii) evaporation.

$$
I_{E}=\frac{2000 P}{\left(\bar{T}_{\text {max }}^{2}-\bar{T}_{\text {min }}^{2}\right)}
$$

where $I_{E}$ is the Emberger climatic coefficient and $P$ is the annual precipitation in millimeters. Parameters $\bar{T}_{\min }$ and $\bar{T}_{\max }$ respectively are averaged values of the maximum temperatures of the warmest month of the year and averaged values of the minimum temperatures of the coldest month in the year. Temperature values in Equation (A1) are expressed in absolute (K) degrees. Table 1 provides classes of the climate conditions referring to the evaluation of $I_{E}$ with Equation (1).

Table A1. Climate classes of Emberger [51] technique.

\begin{tabular}{cc}
\hline $\boldsymbol{I}_{\boldsymbol{E}}$ & Climate Type \\
\hline Over 150 & Hyper-humid \\
$98-150$ & Humid \\
$57-98$ & Sub-humid \\
$30-57$ & Semiarid \\
$17-30$ & Arid \\
\hline
\end{tabular}

\section{Appendix B}

A key parameter of our interest for the analysis of runoff events and the estimate of peak discharge is time of concentration, $t_{c}$ [77]. We used Kirpich [52] formula, which was originally developed for small drainage basins, and characterized it for our test case as follows:

$$
t_{c}=0.0195 L^{0.77} R^{-0.385}
$$

where $L$ and $R$ respectively are basin length and its slope. [52] suggested to multiple the value of $t_{c}$ by 0.4 if the overload flow path is concrete, or by 0.2 if the channel is concrete-lined. 
Rainfall-runoff relationship is characterized through SCS [78] technique, as follows:

$$
Q=\frac{(P-0.2 D)^{2}}{(P+0.8 D)} \text { with } D=\frac{1000}{C N}-10
$$

where $Q$ is the runoff generated by a given precipitation depth of $P$, and $D$ is the maximum storage depth. Curve number, CN, reflects impacts of land use [79].

\section{References}

1. Liu, Y.; Gayle, A.A.; Wilder-Smith, A.; Rocklöv, J. The reproductive number of COVID-19 is higher compared to SARS coronavirus. J. Travel Med. 2020, 1-4. [CrossRef]

2. Mekonnen, M.M.; Hoekstra, A.Y. Four billion people facing severe water scarcity. Sci. Adv. 2016, 2, e1500323. [CrossRef] [PubMed]

3. Wang, X.; Zhang, J.; Gao, J.; Shahid, S.; Xia, X.; Geng, Z.; Tang, L. The new concept of water resources management in China: Ensuring water security in changing environment. Environ. Dev. Sustain. 2018, 20, 897-909. [CrossRef]

4. Christensen, J.H.; Carter, T.R.; Rummukainen, M.; Amanatidis, G. Evaluating the performance and utility of regional climate models: The PRUDENCE project. Clim. Chang. 2007, 81, 1-6. [CrossRef]

5. Sheikh, V. Perception of domestic rainwater harvesting by Iranian citizens. Sustain. Cities Soc. 2020, 60, 102278. [CrossRef]

6. Abbaspour, K.; Faramarzi, M.; Seyed Ghasemi, S.; Yang, H. Assessing the impact of climate change on water resources in Iran. Water Resour. Res. 2009, 45, W10434. [CrossRef]

7. FAO. Progress on Level of Water Stress-Global Baseline for SDG Indicator 6.4.2; License: CC BY-NC-SA 3.0 IGO; FAO: Rome, Italy, 2018; 58p.

8. Yang, H.; Reichert, P.; Abbaspour, K.C.; Zehnder, A.J.B. A water resources threshold and its implications for food security. Environ. Sci. Technol. 2003, 37, 3048-3054. [CrossRef] [PubMed]

9. Moridi, A. State of water resources in Iran. Int. Hydrol. 2017, 1, 111-114. [CrossRef]

10. Makoto, M. Creating rainwater utilization based society for sustainable development. In Proceedings of the International Symposium on Efficient Water Use in Urban Areas, UNEP International Environmental and Technological Center, Kobe, Japan, 8-10 June 1999.

11. Gober, P.; Sampson, D.A.; Quay, R.; White, D.D.; Chow, W.T.L. Urban adaptation to mega-drought: Anticipatory water modeling, policy, and planning for the urban Southwest. Sustain. Cities Soc. 2016, 27, 497-504. [CrossRef]

12. Tabatabaee, J.; Han, M.Y. Rainwater harvesting potentials for drought mitigation in Iran. Water Sci. Technol. 2010, 62, 816-821. [CrossRef]

13. Van der Zaag, P.; Gupta, J. Scale issues in the governance of water storage projects. Water Resour. Res. 2008, 44, W10417. [CrossRef]

14. Van Dijk, S.; Lounsbury, A.W.; Hoekstra, A.Y.; Wang, R. Strategic design and finance of rainwater harvesting to cost-effectively meet large-scale urban water infrastructure needs. Water Res. 2020, 184, 116063. [CrossRef]

15. Campisano, A.; Butler, D.; Ward, S.; Burns, M.J.; Friedler, E.; DeBusk, K.; FisherJeffes, L.N.; Ghisi, E.; Rahman, A.; Furumai, H. Urban rainwater harvesting systems: Research, implementation and future perspectives. Water Res. 2017, 115, 195-209. [CrossRef]

16. Lasage, R.; Verburg, P.H. Evaluation of small scale water harvesting techniques for semi-arid environments. J. Arid Environ. 2015, 118, 48-57. [CrossRef]

17. Vieira, A.S.; Beal, C.D.; Ghisi, E.; Stewart, R.A. Energy intensity of rainwater harvesting systems: A review. Renew. Sustain. Energy Rev. 2014, 34, 225-242. [CrossRef]

18. Naus, F.L.; Burer, K.; van Laerhoven, F.; Griffioen, J.; Ahmed, K.M.; Schot, P. Why Do People Remain Attached to Unsafe Drinking Water Options? Quantitative Evidence from Southwestern Bangladesh. Water 2020, 12, 342. [CrossRef]

19. Ibne Bashar, M.Z.; Rezaul Karim, M.D.; Alam Imteaz, M. Reliability and economic analysis of urban rainwater harvesting: A comparative study within six major cities of Bangladesh. Resour. Conserv. Recycl. 2018, 133, 146-154. [CrossRef]

20. Imteaz, M.A.; Moniruzzaman, M. Spatial variability of reasonable government rebates for rainwater tank installations: A case study for Sydney. Resour. Conserv. Recycl. 2018, 133, 112-119. [CrossRef]

21. Lange, J.; Husary, S.; Gunkel, A.; Bastian, D.; Grodek, T. Potentials and limits of urban rainwater harvesting in the Middle East. Hydrol. Earth Syst. Sci. 2012, 16, 715-724. [CrossRef]

22. Vohland, K.; Barry, B. A review of in situ rainwater harvesting (RWH) practices modifying landscape functions in African dry lands. Agric. Ecosyst. Environ. 2009, 131, 119-127. [CrossRef]

23. Tumbo, S.D.; Mutabazi, K.D.; Byakugila, M.M.; Mahoo, H.F.M. An empirical framework for scaling-out of water system innovations: Lessons from diffusion of water system innovations in the Makanya catchment in Northern Tanzania. Agric. Water Manag. 2011, 98, 1761-1773. [CrossRef]

24. Bouma, J.A.; Hegde, S.S.; Lasage, R. Assessing the returns to water harvesting: A meta-analysis. Agric. Water Manag. 2016, 163, 100-109. [CrossRef]

25. Zhu, K.; Zhang, L.; Hart, W.; Liu, M.; Chen, H. Quality issues in harvested rainwater in arid and semi-arid Loess Plateau of northern China. J. Arid Environ. 2004, 57, 487-505. [CrossRef] 
26. Rahman, S.; Khan, M.T.R.; Akib, S.; BinCheDin, N.; Biswas, S.K.; Shirazi, S.M. Sustainability of rainwater harvesting system in terms of water quality. Sci. World J. 2014, 2014, 721357. [CrossRef]

27. Simmons, G.; Hope, V.; Lewis, G.; Whitmore, J.; Gao, W. Contamination of potable roof-collected rainwater in Auckland, New Zealand. Water Res. 2011, 35, 1518-1524. [CrossRef]

28. Lee, J.Y.; Bak, G.; Han, M. Quality of roof-harvested rainwater-Comparison of different roofing materials. Environ. Pollut. 2012, 162, 422-429. [CrossRef] [PubMed]

29. Ahmed, W.; Gardner, T.; Toze, S. Microbiological quality of roof-harvested rainwater and health risks: A review. J. Environ. Qual. 2011, 40, 13-21. [CrossRef]

30. Ahmed, W.; Hamilton, K.A.; Gyawali, P.; Toze, S.; Haas, C.N. Evidence of avian and possum fecal contamination in rainwater tanks as determined by microbial source tracking approaches. Appl. Environ. Microbiol. 2016, 82, 4379-4386. [CrossRef]

31. Sazakli, E.; Alexopoulos, A.; Leotsinidis, M. Rainwater harvesting, quality assessment and utilization in Kefalonia Island, Greece. Water Res. 2007, 41, 2039-2047. [CrossRef]

32. Helmreich, B.; Horn, H. Opportunities in rainwater harvesting. Desalination 2009, 248, 118-124. [CrossRef]

33. World Health Organization (WHO). Guideline for Drinking Water Quality, 3rd ed.; World Health Organization: Geneva, Switzerland, 2004.

34. Howard, G.; Bartram, J. Vision 2030: The Resilience of Water Supply and Sanitation in the Face of Climate Change; Technical Report; World Health Organization: Geneva, Switzerland, 2010.

35. Ding, C.; He, X. K-means clustering via Principal Component Analysis. In Proceedings of the 21st International Conference on Machine Learning, Banff, AB, Canada, 4-8 July 2004.

36. Ranaee, E.; Ghorbani, H.; Keshavarzian, S.; Ghazaeipour Abarghoei, P.; Riva, M.; Inzoli, F.; Guadagnini, A. Analysis of the performance of a crude-oil desalting system based on historical data. Fuel 2021, 291, 120046. [CrossRef]

37. Jolliffe, I.T. Principal Component Analysis, 2nd ed.; Killough, J.E., Ed.; Springer: New York, NY, USA, 2002.

38. Rousseeuw, P.J. Silhouettes: A graphical aid to the interpretation and validation of cluster analysis. Comput. Appl. Math. 1987, 20, 53-65. [CrossRef]

39. Ahmed, J.; Wong, L.P.; Chua, Y.P.; Channa, N. Drinking Water Quality Mapping Using Water Quality Index and Geospatial Analysis in Primary Schools of Pakistan. Water 2020, 12, 3382. [CrossRef]

40. Kingsborough, A.; Borgomeo, E.; Hall, J.W. Adaptation pathways in practice: Mapping options and trade-offs for London's water resources. Sustain. Cities Soc. 2016, 27, 386-397. [CrossRef]

41. World Health Organization (WHO). Guidelines for Drinking Water Quality, Recommendations; World Health Organization: Geneva, Switzerland, 1981; Volume 1.

42. Iranian Water Resources Management (IWR). Iranian Water Quality Index for Surface Water Resource-Conventional Parameters "IRWQI"; IWRM: Tehran, Iran, 2013.

43. Ayers, R.S.; Westcot, D.W. Water Quality for Agriculture; FAO Irrigation and Drainage Paper 29 (Rev. 1); FAO: Rome, Italy, 1985.

44. Critchley, W.; Siegert, K.; Chapman, C.; Finkel, M. Water Harvesting. A Manual for the Design and Construction of Water Harvesting Schemes for Plant Production; FAO Report; FAO: Rome, Italy, 1991.

45. Babaei, S.F.; Hassani, A.H.; Torabian, A.; Karbassi, A.R.; Hosseinzadeh, L.F. Evolution of a new surface water quality index for Karoon catchment in Iran. Water Sci. Technol. 2011, 64, 2483-2491. [CrossRef]

46. Brown, R.M.; McClelland, N.I.; Deininger, R.A.; Tozer, R.G. A water quality index-do we dare? Water Sew. Work. 1970, 117, 339-343.

47. Nabizadeh, R.; Amin, M.V.; Alimohammadi, M.; Naddafi, K.; Mahvi, A.H.; Yousefzadeh, S. Development of innovative computer software to facilitate the setup and computation of water quality index. J. Environ. Health Sci. Eng. 2013, 11, 1. [CrossRef]

48. Ziyaee, M. Assessment of urban identity through a matrix of cultural landscapes. Cities 2018, 74, 21-31. [CrossRef]

49. Akbari, M.; Modarres, R.; Alizadeh Noughani, M. Assessing early warning for desertification hazard based on E-SMART indicators in arid regions of northeastern Iran. J. Arid Environ. 2020, 174, 104086. [CrossRef]

50. Alizadeh, A. Mathematical Models of Mashhad Study Area; Preliminary Reports of the Ministry of Power; Regional Water Company of Khorasan, Applied Researches Committee: Mashhad, Iran, 2004.

51. Emberger, L. La végétation de la region méditérranéenne. Essai d'une classification des groupements végétaux. Rev. Bot. 1930, $504,705-721$.

52. Kirpich, Z.P. Time of concentration of small agricultural watersheds. Civ. Eng. 1940, 10, 362.

53. Eaton, A.D.; Franson, M.A.H. Standard Methods for the Examination of Water and Waste Water; American Public Health Association: Washington, DC, USA, 2005.

54. Abbasi, A.A.; Tabatabaee, J.; Ranaee, E. Rainwater Harvesting and Consumption in Urban Area. In Proceedings of the EGU General Assembly, Vienna, Austria, 7-12 April 2013.

55. Pandit, A.; Heck, H.H. Estimations of soil conservation service curve numbers for concrete and asphalt. Hydrol. Eng. 2009, 14, 335-345. [CrossRef]

56. APHA. Standard Methods for the Examination of Water and Wastewater, American Public Health Association, 16th ed.; American Water Works Association and Water Pollution Control Federation: Washington, DC, USA, 1989.

57. Appan, A. Economic and water quality aspects of rainwater catchment system. In Proceedings of the International Symposium on Efficient Water Use in Urban Areas, UNEP International Environmental and Technological Center, Kobe, Japan, 8-10 June 1999. 
58. Rusydi, F.A. Correlation between conductivity and total dissolved solid in various type of water: A review. In IOP Conference Series: Earth and Environmental Science; IOP Publishing: Bristol, UK, 2018; Volume 118, p. 012019. [CrossRef]

59. Ranaee, E.; Porta, G.M.; Riva, M.; Guadagnini, A. Investigation of Saturation Dependency of oil Relative Permeability during WAG setting through Linear and Non-Linear Principal Component Analysis. In Proceedings of the ECMORXIV-14th European Conference on the Mathematics of oil Recovery, EAGE, Sicily, Italy, 8-11 September 2014. [CrossRef]

60. Chang, M.; Matthew, W.; McBroom, R.; Beasley, S. Roofing as a Source of Nonpoint Water Pollution. Environ. Manag. 2004, 73, 307-315. [CrossRef]

61. Council Directive 91/271/EEC of 21 May 1991 concerning urban waste-water treatment. J. Eur. Commun. 1991, 34, 40-52.

62. Scholz, M. Design, Operation, Maintenance and Water Quality Management of Sustainable Storm Water Ponds for Roof Runoff. Bioresour. Technol. 2004, 95, 269-279. [CrossRef] [PubMed]

63. John, D.M.; Whitton, B.A.; Brook, J.A. The Freshwater Algal Flora of the British Isles, 1st ed.; Cambridge University Press: Cambridge, UK, 2002; p. 702. ISBN 0-521-77051-3.

64. Rahman, A.; Dbais, J.; Islam, S.M.; Eroksuz, E.; Haddad, K. Rainwater Harvesting in Large Residential Buildings in Australia. In Urban Development; Polyzos, S., Ed.; IntechOpen: London, UK, 2012; pp. 159-178. [CrossRef]

65. Prinz, D. Water harvesting technique in Mediterranean region. In Proceedings of the International Seminar Rainwater Harvesting and Management in Arid and Semiarid Areas, Lund, Sweden, 29 June-2 July 1998; Lund University Press: Lund, Sweden, 1999.

66. FAO. Review of World Water Resources by Country; Water Reports 23; FAO: Rome, Italy, 2003.

67. Wisser, D.; Frolking, S.; Douglas, E.M.; Fekete, B.M.; Schumann, A.H.; Vörösmarty, C.J. The significance of local water resources captured in small reservoirs for crop production-A global-scale analysis. J. Hydrol. 2010, 384, 264-275. [CrossRef]

68. Ranaee, E.; Mahmoodian, M.; Rahati, S. The Combination of HEC-Geo-HMS, HEC-HMS and MIKE11 Software Utilize in a Two Branches River Flood Routing Modeling. In Proceedings of the Second International Conference on Environmental and Computer Science, Dubai, United Arab Emirates, 28-30 December 2009; IEEE Computer Society Press: Piscataway, NJ, USA, 2009; pp. 317-321. [CrossRef]

69. Tavakol-Davani, H.; Goharian, E.; Hansen, C.H.; Tavakol-Davani, H.; Apul, D.; Burian, S.J. How does climate change affect combined sewer overflow in a system benefiting from rainwater harvesting systems? Sustain. Cities Soc. 2016, 27, 430-438. [CrossRef]

70. Nachshon, U.; Netzer, L.; Livshit, Y. Land cover properties and rainwater harvesting in urban environments. Sustain. Cities Soc. 2016, 27, 398-406. [CrossRef]

71. Glendenning, C.J.; van Ogtrop, F.F.; Mishra, A.K.; Vervoort, R.W. Balancing watershed and local scale impacts of rainwater harvesting in India-A review. Agric. Water Manag. 2012, 107, 1-13. [CrossRef]

72. Smajgl, A.; Ward, J.; Pluschke, L. The water-food-energy Nexus-Realizing a new paradigm. J. Hydrol. 2016, 533, 533-540. [CrossRef]

73. Hedegaard, M.J.; Albrechtsen, H.J. Microbial pesticide removal in rapid sand filters for drinking water treatment-Potential and kinetics. Water Res. 2014, 48, 71-81. [CrossRef] [PubMed]

74. Kim, R.H.; Lee, S.; Kim, J.O. Application of a metal membrane for rainwater utilization: Filtration characteristics and membrane fouling. Desalination 2005, 177, 121-132. [CrossRef]

75. McGuigan, K.G.; Conroy, R.M.; Mosler, H.; Du Preez, M.; Ubomba-Jaswa, E.; Fernandezlbañez, P. Solar water disinfection (SODIS): A review from bench-top to roof-top. J. Hazard. Mater. 2012, 235-236, 29-46. [CrossRef]

76. Clark, P.A.; Pinedo, C.A.; Fadus, M.; Capuzzi, S. Slow-sand water filter: Design, implementation, accessibility and sustainability in developing countries. Med. Sci. Monit. 2012, 18, RA105-RA117. [CrossRef] [PubMed]

77. Fang, X.; Thompson, D.; Cleveland, T.G.; Pradham, P.; Malla, R. Time of concentration estimated using watershed parameters by automated and manual methods. Irrig. Drain. Eng. 2008, 134, 202-211. [CrossRef]

78. Soil Conservation Service. Urban Hydrology for Small Watersheds; Technical Release TR-55; Soil Conservation Service, Hydrology Unit, USDA: Washington, DC, USA, 1986.

79. Alizadeh, A. Principals of Applied Hydrology, 29th ed.; University of Imam Reza Press: Mashhad, Iran, 2010 ; p. 912. 